ORIGINAL RESEARCH

\title{
Clinical Strains of Pseudomonas aeruginosa secret LasB protease to induce hemorrhagic diffused alveolar damage and acute lung injury in mice
}

Yajie Zhu ${ }^{1 \mathrm{MD}}$, Xiaoli Ge ${ }^{1 \mathrm{MD} P \mathrm{PhD}}$, Di Xie ${ }^{1 \mathrm{MD}}$, Shangyuan Wang ${ }^{1 \mathrm{MD}}$, Feng Chen ${ }^{2 \mathrm{MD} P \mathrm{PhD} *}$ and Shuming Pan ${ }^{1 \mathrm{MD} P h D *}$

${ }^{1}$ Department of Emergency Medicine, Xinhua Hospital, Shanghai Jiao Tong University School of Medicine, Shanghai 200092, China

${ }^{2}$ Division of Medical Microbiology, Department of Clinical Laboratory, Xinhua Hospital, Shanghai Jiao Tong University School of Medicine, No. 1665, Kongjiang Road, Yangpu District, Shanghai 200092, China

${ }^{*}$ Corresponding authors :

Shuming Pan, Department of Emergency, No. 1665, Kongjiang Rd., Shanghai, China

Tel.: +8602125076045; Fax: +8602165030840; Email: panshuming@xinhuamed.com.cn

Feng Chen, Division of Medical Microbiology, Department of Clinical Laboratory, No. 1665, Kongjiang Rd., Shanghai, China

Tel.: +8602125078999; Fax: +8602165030840; Email: chenfeng@xinhuamed.com.cn

\section{Authors' Contributions}

Yajie Zhu and Feng Chen contributed to the conception of the study; Yajie Zhu, Feng Chen, Xiaoli Ge, Di Xie, Shangyuan Wang performed the experiment; All authors contributed to data analysis and manuscript preparation; Shuming Pan was responsible for the study supervision and coordination. All authors critically reviewed the manuscript for important intellectual content, read and approved the final manuscript.

\section{Disclosure of potential conflicts of interest:}

The authors declare no conflicts of interest in this work.

\section{Funding}

National Natural Science Foundation of China. NSFC NO.81772111. 


\begin{abstract}
Background: Acute lung injury and acute respiratory distress syndrome are most often caused by bacterial pneumonia, characterized by severe dyspnea and high mortality. Knowledge about the lung injury effects of current clinical bacteria strains is lacking. The aim of this study was to investigate the ability of representative pathogenic bacteria isolated from patients to cause ALI/ARDS in mice and identify the virulent factors.
\end{abstract}

Method: 7 major bacteria species were isolated from clinical sputum and instilled in to mice airway unilaterally. Histology study was used to judge the lung injury effect. Virulence genes were examined by PCR. Sequence type of $P$. aeruginosa strains were identified by MLST. LC-MS/MS was used to identify the suspicious protein bands. LasB was purified through DEAE-cellulose column and its toxicity was tested both in vitro and in vivo.

Results: Staphylococcus aureus, Streptococcus pneumoniae, Streptococcus agalactiae, Acinetobacter baumannii, Klebsiella pneumoniae, Pseudomonas aeruginosa and Escherichia coli were randomly separated and tested 3 times. Among them, gram-negative bacteria are more potential than gram-positive bacteria to cause acute lung injury. However, $P$. aeruginosa is the only pathogen which induced diffused alveolar damage, hemorrhage and hyaline membrane in the lung of mice. The lung injury effect is associated to the excreted matrix metalloproteinase LasB of $P$. aeruginosa. Purified LasB recapitulated hemorrhagic acute lung injury identical to $P$. aeruginosa infection in vivo. We found this was due to the powerful degradation effect of LasB on both lung extracellular matrix and key proteins in coagulation cascade without inducing cellular apoptosis. 
bioRxiv preprint doi: https://doi.org/10.1101/2021.05.15.444319; this version posted May 15, 2021. The copyright holder for this preprint (which

was not certified by peer review) is the author/funder, who has granted bioRxiv a license to display the preprint in perpetuity. It is made available under aCC-BY-NC-ND 4.0 International license.

Conclusion: $P$. aeruginosa strains are most capable to induce ALI/ARDS among major clinical pathogenic bacteria, this ability is specifically attributed to their LasB production.

Key words: unilateral lung injury, LasB elastase, Pseudomonas aeruginosa, ALI/ARDS; 


\section{Clinical Strains of Pseudomonas aeruginosa secret LasB protease to induce hemorrhagic diffused alveolar damage and acute lung injury in mice}

\section{Introduction}

Acute lung injury (ALI) and its more serious form acute respiratory distress syndrome (ARDS)

is a major killer in the ICU. Despite decades of efforts, the pathogenesis of ALI/ARDS remains unclear, let alone effective treatment[1]. Diffused alveolar damage (DAD), hyaline membrane formation and alveolar bleeding which are common pathology features found in ALI/ARDS patients, were poorly recapitulated in animal models. Furthermore, although it is defined as a syndrome of similar clinical signs associated with damage to the alveolar-capillary membrane, the heterogenicity in ARDS have been more and more recognized [2].

The major risk factor of ARDS is pneumonia caused by various microorganisms, accounting for nearly $60 \%$ of the cases[3]. Microorganisms like bacteria or virus, evolves rapidly in response to environment for better adaption and survival [4-6]. Compared to the type strains or standard strains preserved and studied in lab for decades, clinical isolates nowadays are exhibiting significant differences in phenotype, drug resistance and invasiveness[7-9]. However, virulence of this "new generation" of bacteria in causing lung injury have not been comparatively explored.

Sputum culture are routinely prescribed for patients suspected or diagnosed with pneumonia. According to the yearly report of China Antimicrobial Surveillance Network (CHINET), Klebsiella pneumoniae, Acinetobacter baumannii, Pseudomonas aeruginosa, Staphylococcus aureus, Streptococcus pneumoniae and Escherichia coli are the 6 species most commonly 
found, accounting for $70.5 \%$ of the 90955 strains separated from clinical respiratory specimens nationwide in 2020. Coinfection of different bacteria species is usual in pneumonia patients, sometimes even secondary to virus or fungus infection[10,11]. Are these pathogenic bacteria equally virulent in causing lung tissue injury? This led us to wonder perhaps there is one or some bacteria particularly have dominated in the pathogenesis of ALI or even ARDS.

As Xinhua hospital is a member of CHINET[12], the bacteria prevalence here is a representative part of the status in China. In this study, we selected to isolate the 6 major bacteria species listed above plus Streptococcus agalactiae from clinical sputum, based on both the data from CHINET and our own hospital. Since the most relevant features of ALI/ARDS in animal models are rapid onset (within $24 \mathrm{~h}$ ) and histological evidence of tissue injury[13], our research mainly applied histopathology methods to visualize lung injury $24 \mathrm{~h}$ post treatment. To better illustrate the effect of each bacteria, we applied a unilateral lung injury model by inoculating microorganisms specifically into the left lung while keeping right lung unharmed as control. This relieved dyspnea, allowed mice to survive until the intended time and formed a natural comparison within the individual for comparison.

We found that among all the species, $P$. aeruginosa is the only bacteria caused classic ALI/ARDS pathology change in mice, characterized by severe hemorrhage, diffused alveolar damage and hyaline membrane formation. We discovered this is caused by the LasB elastase (pseudolysin) which degraded the lung matrix and key proteins in coagulation pathway.

\section{Materials and methods}




\section{Ethical statement}

All experiments referring to the use of animals in this study were approved by the Institutional

Animal Care and Use Committee of Shanghai Xinhua Hospital affiliated to Shanghai Jiao Tong University School of Medicine (XHEC-F-2018-047).

\section{Animals}

Pathogen-free C57BL/6 mice (female, 10 weeks old, 21 $\pm 1 \mathrm{~g}$ ), SD rats (female, 6-8 weeks old, $200 \pm 10$ g) were purchased from Shanghai Sippr-BK laboratory animal Co. Ltd. All animals were accommodated at the Model Animal Research Center of Xinhua Hospital in a specific pathogen-free animal facility under constant temperature and humidity, with sufficient qualified food and water for 1 weeks before use.

\section{Unilateral intratracheal instillation}

In mouse, we select the left lung for bacteria or bacteria exoproducts administration.

Meanwhile, the right lung was set as the control lung within each individual. To perform

unilateral lung intubation, a 24G, 19mm long intravenous indwelling catheter (Introcan,

BRAUN) was used as the intratracheal tube and inserted through a cervical incision. Mice

were anesthetized by $1 \%$ pentobarbital sodium $(50 \mathrm{mg} / \mathrm{Kg})$ intraperitoneally and put to a proper

supine position. The anterior cervical hair was removed and the skin disinfected with $75 \%$

ethanol. In order to expose the trachea, a small longitudinal incision was made. The indwelling

catheter was then punctured gently into the trachea between the second and third cricoid

cartilage. As anatomical data shows that the mouse main trachea is approximately $10 \mathrm{~mm}$ long, 
therefore the $19 \mathrm{~mm}$ cannula full length inserted will enter the left or right bronchus. Left bronchus intubation was achieved when the insertion angle is $5-10^{\circ}$ to the anterior median line as indicated in Figure 1A. Then, $25 \mu \mathrm{l}$ bacteria suspension or $30 \mu \mathrm{l} \mathrm{P}$. aeruginosa exoproducts were deposited into the left lung of each mouse using microliter syringes. After instillation, mice were placed on a warm blanket, resting to left recumbent position until fully awake.

\section{Lung histopathology}

Mice were sacrificed at $24 \mathrm{~h}$ post-infection. The lung was inflated with $4 \%$ paraformaldehyde fixative under constant pressure of 15 to $25 \mathrm{~cm} \mathrm{H} 2 \mathrm{O}$ via the trachea by standard procedures[14]. Lung and heart were harvested en bloc and submerged in fixative for approximately 24 hours before the heart was removed. The lung was embedded in paraffin block for tissue sections $(5 \mu \mathrm{m})$. Hematoxylin and eosin staining or TUNEL staining were performed subsequently. ALI score was performed as described[13]. The modified ALI score substituted the item "Neutrophils in the interstitial space" to "Red blood cells in the alveolar space" to better differentiate the severity of lung injury resulted from P. aeruginosa exoproducts.

\section{Clinical isolates}

Major bacteria species were separated from clinical sputum specimen based on morphology, confirmed by mass spectrometry and stored at $-70^{\circ} \mathrm{C}$. For enrichment culture, non-fastidious bacteria: Staphylococcus aureus, Streptococcus agalactiae, Acinetobacter baumannii, Klebsiella pneumoniae, Pseudomonas aeruginosa and Escherichia coli were inoculated into 
LB broth (Beyotime, China) incubated overnight at $36 \pm 1^{\circ} \mathrm{C}, 60 \mathrm{rpm}$. Fastidious bacteria:

Streptococcus pneumoniae was cultured on sheep blood agar plates (Yi Hua, Shanghai)

overnight at $36 \pm 1^{\circ} \mathrm{C}, 5 \% \mathrm{CO} 2$. Bacteria from exponential growth were collected, washed twice

and resuspended in sterile normal saline (NS). The turbidity was adjusted to 3 McFarland

standards (MCF), which equals $9 \times 108 \mathrm{CFU} / \mathrm{ml}$, by the standard procedure for later use. Each

of the 7 species was isolated and prepared as above three times randomly.

\section{$P$. aeruginosa strains and exoproducts}

A total of $8 P$. aeruginosa strains were randomly isolated from clinical respiratory tract

specimen. They are named as Pa 1-6 according to the separation time, plus a mucoid strain

named as $\mathrm{Pa} \mathrm{M}$ and a strain used in the earlier experiments as $\mathrm{Pa} \mathrm{J}$ (isolated in July). The

growth medium for routine harvesting of $P$. aeruginosa exoproducts was Columbia agar

supplied with 5\% sheep blood (90 mm, Comagal, Shanghai). The entire agar surface was

inoculated with a cotton swab. Plates were incubated at $36 \pm 1^{\circ} \mathrm{C}$ for 3 days. Bacteria and

exoproducts on the plate were dissolved in sterile NS ( $5 \mathrm{ml}$ per plate). Bacteria cells were

removed after centrifugal for $3200 \times \mathrm{g}, 30 \mathrm{~min}$ and further cleared by $0.22 \mu \mathrm{m}$ filters. Then the

exoproducts acquired was concentrated by ultra-centrifugal filters at $3000 \times \mathrm{g}, 30 \mathrm{~min}(10 \mathrm{kDa}$

cutoff value, Amicon Ultra, Merck). Protein level was measured through BCA method. All

exoproducts were adjusted to the same protein concentration by adding sterile NS.

\section{PCR and MLST}

Virulence genes were detected by PCR. Briefly, a single colony of $P$. aeruginosa was added to 
$1 \mathrm{ml} \mathrm{ddH2O}$, washed twice and resuspended. We extracted bacterial DNA by boiling the suspension for $10 \mathrm{~min}$ at $100{ }^{\circ} \mathrm{C}$. Using pairs of specific primers (Table S1), we examined the presence or absence of the following genes among clinical isolates of $P$. aeruginosa: aprA, toxA, lasA, lasB, plcH, prpL, exoS, exoY, exoT, exoU, lepA, phzS, rhlR, mucA, algR and fliC

(Table 1). PCR amplifications were performed in $50 \mu \mathrm{l}$ reaction mixtures. Based on product size (Table S1), genes were identified and recorded as positive (+) or negative (-).

For multilocus sequence typing, seven house-keeping genes: acsA, aroE, guaA, mutL, nuoD, ppsA, trpE were amplified and sequenced according to standard procedures[15](Sangon, Shanghai). Allele type and sequence type were acquired by querying on PubMLST website[16].

\section{SDS-PAGE}

$10 \%$ gel was used for SDS-PAGE of exoproducts or proteins under $150 \mathrm{~V}$ constant voltage.

\section{Gelatin zymography}

Gelatin zymography was performed as reported by Kessler and colleges[17]. 8\% gel containing $0.1 \%$ gelatin was used in SDS-PAGE. P. aeruginosa exoproducts ( $2 \mathrm{mg}$ protein $/ \mathrm{ml}$ ) were preincubated with $25 \mathrm{mM}$ EDTA or NS for $30 \mathrm{~min}$ at room temperature. $3.5 \mu \mathrm{g}$ of each sample (measured by protein) was mixed with non-reducing loading buffer ( $1 \%$ SDS added), without boiling, loaded at interval wells to avoid cross-contamination. Electrophorese was performed at $4{ }^{\circ} \mathrm{C}, 110 \mathrm{~V}$ constant voltage. The gels were washed twice before transferred to incubate within $200 \mathrm{ml}$ development buffer (Tris-HCl $50 \mathrm{mM} \mathrm{pH}$ 7.5, $\mathrm{CaCl} 25 \mathrm{mM}, \mathrm{NaCl} 0.2 \mathrm{M}$, 
Brij-35 $0.02 \%$ ) for $16-20 \mathrm{~h}$ at $37^{\circ} \mathrm{C}$. At last, gels were stained by Coomassie blue dye R-250

$(0.25 \%)$ for $1 \mathrm{~h}$, decolorized by destainer (methanol $20 \%$, acetic acid $10 \%, 70 \% \mathrm{ddH}_{2} \mathrm{O}$ ) until

clear bands were seen, and scanned by Amersham Imager (Al680, GE).

\section{Protease assays}

$P$. aeruginosa exoproducts and purified LasB were tested for elastase activity using

Elastin-Congo red (Sigma) method[17]. EnzChek Elastase Assay Kit (Thermo Fisher Scientific)

was used to monitor the proteolytic activity of eluted fractions in chromatography process

according to the manufacturer's instructions.

\section{Fibrinogenolytic and fibrinolytic activities}

Fibrinogenolytic activity was assayed using bovine fibrinogen as a substrate. Exoproducts of

Pa 1-6, M, J (1 mg protein/ml) and porcine elastase (50 U/ml) were preincubated with protease inhibitor cocktail (17 mM AEBSF, $2.5 \mu \mathrm{M}$ Aprotinin, $1 \mathrm{mM}$ Bestatin, $0.1 \mathrm{mM}$ E64 and $0.1 \mathrm{mM}$ Leupeptin in DMSO) or EDTA (8.5 mM) at room temperature for $30 \mathrm{~min} .100 \mu \mathrm{l}$ of fibrinogen solution ( $4 \mathrm{mg} / \mathrm{ml}$ in saline) was mixed with $10 \mu \mathrm{l}$ of each sample and incubated at $37^{\circ} \mathrm{C}$ for $1 \mathrm{~h}$. $5 \mu \mathrm{l}$ of the product from each sample was subjected to SDS-PAGE.

For the fibrinolytic activity, $50 \mu$ fibrinogen ( $6 \mathrm{mg} / \mathrm{ml}$ in PBS) and 30 units of thrombin were mixed in a $200 \mu \mathrm{l} \mathrm{PCR}$ tube, and preincubated for $15 \mathrm{~min}$ at $37^{\circ} \mathrm{C}$ to form the fibrin clot. Then, $15 \mu \mathrm{l}$ exoproducts ( $1 \mathrm{mg}$ protein $/ \mathrm{ml}$ ) were added to each tube and incubated for $1 \mathrm{~h}$ at $37^{\circ} \mathrm{C}$.

The sample was gently stirred using a syringe needle to check for fibrin fibers, and the solubility of fibrin was observed. 


\section{Thrombin degradation activity}

Exoproducts of $\mathrm{Pa} 1-6, \mathrm{M}$ and $\mathrm{J}(1 \mathrm{mg}$ protein $/ \mathrm{ml})$ were preincubated with $100 \mathrm{mM}$ EDTA at room temperature for $30 \mathrm{~min}$. $2 \mu \mathrm{l}$ of each sample was mixed with $100 \mu \mathrm{l}$ bovine thrombin solution $(2 \mathrm{mg} / \mathrm{ml})$ and incubated at $37^{\circ} \mathrm{C}$ for $1 \mathrm{~h} .5 \mu \mathrm{l}$ of the mixture was subjected to SDS-PAGE. The thrombin activity was also measured, by mix $5 \mu$ l of each product with $50 \mu \mathrm{l}$ fibrinogen $\left(6 \mathrm{mg} / \mathrm{ml}\right.$ in PBS), incubated at $37^{\circ} \mathrm{C}$ for $15 \mathrm{~min}$ and then checked for fibrin fibers formation.

\section{Proteomic analysis}

Exoproducts from different strains were separated on $10 \%$ polyacrylamide gel electrophoresis (SDS-PAGE) and stained with Coomassie blue. The whole lane or certain protein bands of interest were excised from the gel and processed by mass spectrometer (LTQ Orbitrap Velos

Pro, Thermo Finnigan) coupled to liquid chromatography as described[18]. Mascot 2.3 software was used for data analysis.

\section{Purification of LasB}

The protease was purified by ammonium sulphate precipitation followed by DEAE-cellulose chromatography. P. aeruginosa strain Pa 4 was cultivated on Columbia agar plates $(90 \mathrm{~mm})$ supplied with $5 \%$ sheep blood at $37^{\circ} \mathrm{C}$ for 3 days (For each chromatography column we use 8 plates). Each plate was washed by $8-10 \mathrm{ml} 20 \mathrm{mM}$ Tris- $\mathrm{Cl}$ buffer ( $\mathrm{pH}$ 8.0). After centrifugated for $3200 \times \mathrm{g}, 60$ minutes, the pellet (bacterial cells) was discarded. Ammonium sulphate was added to the supernatant up to $20 \%$ saturation, sediments removed by centrifugation at $3200 \times$ 
g for $30 \mathrm{~min}$, and continued up to $80 \%$ saturation, precipitates were collected by the same way and resuspended in $20 \mathrm{mM}$ Tris- $\mathrm{Cl}$ buffer ( $\mathrm{pH}$ 7.5). This crude enzyme solution was desalted using ultra centrifugal filters of $10 \mathrm{kDa}$ cutoff value (Amicon Ultra, Merck) and then loaded on a $15 \mathrm{~mm} \times 200 \mathrm{~mm}$ DEAE cellulose column pre-equilibrated with $20 \mathrm{mM}$ Tris-Cl buffer ( $\mathrm{pH}$ 7.5). After washing the column with the same buffer, elastase was eluted by applying a linear gradient of $\mathrm{NaCl}$ from 0 to $1000 \mathrm{mM}$ at a flow rate of $0.34 \mathrm{ml} / \mathrm{min}$. Fractions of $2.5 \mathrm{ml}$ were collected. Activity of the fractions were measured using EnzCheck Elastase Assay Kit (Thermo Fisher). Active fractions were concentrated by ultracentrifugation described as above and stored $-20^{\circ} \mathrm{C}$ for later use.

\section{Cytotoxicity assay}

THP-1 cells were seeded in 96-well plates with 1640 medium containing $10 \%$ fetal bovine serum. Purified LasB in concentration of $100 \mu \mathrm{g} / \mathrm{ml}, \mathrm{Pa} 4$ exoproducts in concentration of 200

$\mu \mathrm{g} / \mathrm{ml}$ or Pa 4 bacteria $7.5 \times 10^{7} \mathrm{CFU} / \mathrm{ml}$ were added to wells. Cytotoxicity was measured by LDH release 4 hours post incubation using a LDH cytotoxicity assay kits (Beyotime Biotechnology) according to the manufacturer's instruction.

\section{Hemostasis function}

To examine the effect on hemostasis function, $20 \mu \mathrm{g}$ LasB was added to $2 \mathrm{ml}$ blood $(1.8 \mathrm{ml}$ blood $+0.2 \mathrm{ml}$ sodium citrate anticoagulant) from healthy volunteers, incubated for $35 \mathrm{~min}$ at room temperature. The samples were then subjected to automatic hemostasis tests by ACL TOP (550 CTS, Werfen). 


\section{Statistics}

The data were expressed as the mean \pm standard error of mean. Statistical analysis was

performed in the GraphPad Prism 8 software using one-way or two-way t-test or log rank test

as appropriate. Statistical significance is indicated as $\left({ }^{*}, \mathrm{P}<0.05 ;{ }^{* *}, \mathrm{P}<0.005 ;{ }^{* *}, \mathrm{P}<\right.$

0.0005). Data are representative of at least three independent experiments.

\section{Results}

\section{Unilateral lung injury in mice}

We used a unilateral lung injury model in this study through tracheotomy and intubation into the left lung of the mice. We verified the method through LPS instillation. As shown by CT scan (3D reconstruction) in Figure $1 \mathrm{~A}$, the instillation of $30 \mu \mathrm{l} 5 \mathrm{mg} / \mathrm{ml}$ LPS successfully induced consolidation of the whole left lung in 4 hours.

This animal model was initially designed to see if heavy unilateral lung injury would provoke bilateral alveolar damage through systemic impacts like cytokine storm, whereas, we could find no such phenomenon in mice tested with LPS, acid, porcine elastase or mechanical ventilation, even if severe inflammation and animal death were observed (unpublished data). The untreated lung in unilaterally injured mice exhibited no difference to the lung from intact normal mice (Figure S1A).

\section{Gram-positive bacteria lung infection}

$2.25 \times 10^{7} \mathrm{CFU}$ of $S$. aureus, S. agalactiae or $S$. pneumoniae suspended in $25 \mu$ PBS were 
instilled into the left lung of mice to study the lung injury effect in vivo. Much to our surprise, all mice groups remained healthy $24 \mathrm{~h}$ post inoculation, and had no symptoms of acute lung injury such as dyspnea, weight loss or reduced activity. Similar in all three gram-positive bacteria infected groups, lung histology found no visible alveolar damage. We did find a few coccus in the in the infected lung in contrast with the control lung, however, they were located in the cytoplasm of alveolar macrophages (Figure 1B), suggesting the infection were already in control of the immune cells.

Considering the daily isolated gram-positive bacteria may have relatively low virulence, we further tested a highly virulent mucoid serotype 3 S. pneumoniae strain and a hypervirulent $S$. agalactiae strain isolated earlier, of which we had to reduce the bacteria number to $2.25 \times 10^{5}$ CFU and $1.5 \times 10^{7} \mathrm{CFU}$ respectively to keep the inoculated mice live to $24 \mathrm{~h}$ endpoint. However, no visible alveolar damage occurred either in both groups after treatment, even though $50 \%$ mice died within 24 hours or developed seizure, sepsis and multiple organ infection (Figure S1B). Neutrophil accumulation, red blood cell effusion and large amount of coccus appeared in the interstitial space of pulmonary arteries, however, without provoking inflammation in the alveolar space (Figure 1B).

These results imply that irrelevant to their virulence, the gram-positive bacteria isolated from clinical sputum evoked a lung injury pattern more similar to bronchial pneumonia rather than the diffused alveolar damage found in ALI/ARDS.

\section{Gram-negative bacteria lung infection}


Next, we tested the pathogenicity of the major gram-negative bacteria species, which together account for $60 \%$ of all clinical respiratory isolates. Mice were instilled with $25 \mu$ l bacteria suspensions $\left(2.25 \times 10^{7} \mathrm{CFU}\right)$ of Klebsiella pneumoniae, Acinetobacter baumannii, Escherichia coli or Pseudomonas aeruginosa. This time, alveolar injury of different degrees occurred in all animals 24 hours after inoculation.

Interestingly, the lung injury caused by K. pneumoniae was noted for large number of leukocytes accumulated in the alveolar wall while the alveolar space filled with mucus, which was later proved to be all $K$. pneumoniae with thick capsular structure (Figure $1 \mathrm{C}$ \&Figure S1C). We don't know yet if infection of $K$. pneumoniae had disabled the infiltration ability of neutrophils or the bacteria had digested the neutrophils infiltrated. Empyema was found in $80 \%$ of mice $(n=10)$, probably due to the fact that $K$. pneumoniae isolated in our hospital for recent years are mainly hypermucoviscous, i.e., hypervirulent type.

Lungs infected with $A$. baumannii and $E$. coli both showed evidence of alveolar inflammation. E. coli triggered more diffused neutrophil accumulation in the alveolar space than the patchy pattern in A. baumannii. However, no septal thickening, hyaline membrane formation or red blood cell effusion were found in both bacteria.

Strikingly, $P$. aeruginosa strains from 3 independent isolation all caused hemorrhage, severe hyaline membrane formation, neutrophilic infiltration, parenchymal edema and proteinaceous debris deposit in the infected lungs, fitting with the histologic change of diffused alveolar damage. 
We then compared the ALI score of each species. Generally, gram-negative bacteria achieved higher score than gram-positive bacteria, indicating they are stronger pulmonary damaging pathogens. Distinguished from all bacteria species, $P$. aeruginosa is the one and only one acquired the highest score, suggesting its great potence in ALI/ARDS pathogenesis. To know if this injury effect is a common feature or by chance, we further isolated more $P$. aeruginosa strains.

\section{ALI by strains of $P$. aeruginosa in vivo.}

To examine the virulence in vivo, 8 P. aeruginosa strains: $\mathrm{Pa} 1-6, \mathrm{~Pa} \mathrm{M}$ and $\mathrm{Pa} \mathrm{J}$ were stilled in mouse airways and survival curves were established. Quality control strain ATCC27853 was used as the control. Surprisingly, all $P$. aeruginosa strains induced hemorrhagic diffused alveolar damage in vivo (Figure 2C, Figure S2A). ATCC27853 is the least virulent in all, and $\mathrm{Pa} 3$ is the least virulent among clinical isolates (Figure 2A). Pa 2 is less toxic than Pa 4, 5, 6 $(\mathrm{p}=0.003)$, but more toxic than $\mathrm{Pa} 1,3, \mathrm{M}$ and $\mathrm{J}(\mathrm{p}<0.0001)$.

Mice instilled with Pa 2 and Pa 4, 5, 6 all died within 24 h. Pink frothy sputum or bloody sputum were seen excreting from the nose and mouth in 50\% of the animals (Figure 2B). Autopsy found strain $\mathrm{Pa}$ 4, 5, 6 caused similar pathology change prominent with lung hemorrhage. Alveolar were inundated by red blood cells, accompanied with structural destruction, neutrophils infiltration and septal thickening (Figure 2D). Also, $87 \%$ mice infected unilaterally with these 3 strains developed bilateral lung injury, suggesting that $\mathrm{Pa} 4,5,6$ are highly deleterious. However, in the uninoculated lungs, hyaline membrane formation and red blood cell effusion were mostly observed around the bronchus or bronchia instead of alveoli, 
indicating the injury was likely been caused by aspiration of the bloody sputum or bacteria from the infected lung.

\section{Virulence genes}

$P$. aeruginosa are known for owning a plethora of virulence factors, represented by T1SS,

T2SS, T3SS, T6SS and quorum sensing system. T1SS and T2SS exert wide range damaging effect through secreted toxin A or proteases. Conversely, T3SS and T6SS inject several toxins into nearby cells directly. To explore the molecular mechanisms of P. aeruginosa pathogenicity, we set up PCR tests to examine the possible virulence genes. All strains are positive with toxA, aprA, lasB, las A, plcH, prpL, lepA which are genes most related to T1SS and T2SS.

Differences were detected in T3SS (exoS and exoT) and bacterial structure genes, however, the differences are not related to their level of virulence tested earlier (Table 1).

We then compared the antibiotic resistance and pyocyanin production (Table 2). Pa 2 showed resistance to Cefoperazone-sulbactam, Meropenem and Levofloxacin, while fortunately, $\mathrm{Pa}$ 4, 5, 6 were still sensitive to all three antibiotics, meaning their virulence were not related to drug resistant ability either. We also ruled out pyocyanin, for only $\mathrm{Pa} 1$ and $\mathrm{Pa} \mathrm{J}$ produced pyocyanin.

Judged from morphology (Figure S2B), Pa 4, 5, and 6 were very similar. To know if they were actually the same, we performed multilocus sequence typing (MLST) on 8 isolates.

However, all 8 isolates have different sequence types. From them, four new sequence type of P. aeruginosa: strain $\mathrm{Pa}$ 3, 5, 6 and $\mathrm{M}$ were identified. A new allele type of ppsA from $\mathrm{Pa} 3$ was 
found (Table 3). Allelic profiles and the ST types of the isolates are shown in Table 3.

\section{Exoproducts induced ALI}

Enlightened by the results of PCR, we decided to test the virulence of the secreted exoproducts from $P$. aeruginosa. As shown in Figure 3A, the exoproducts reproduced the typical histologic change of $P$. aeruginosa infection in lung. After instilled with high concentration of exoproducts collected from 8 P. aeruginosa strains (4 $\mathrm{mg}$ protein $/ \mathrm{ml})$, severe hemorrhage and DAD were observed in all mice ( $n=3$ mice, 8 group). To our surprise, 14 of 24 mice died within 3 hours. Autopsy found tension pneumothorax and atelectasis of the whole left lung in them. On the contrary, survived mice presented emphysematous alveolar destruction, suggesting pneumothorax caused by exoproducts was most likely responsible for the sudden death in mice.

Interestingly, after been heated at $100^{\circ} \mathrm{C}$ for 10 minutes, the exoproducts lost the ability to cause alveolar hemorrhage or destruction, but only evoked neutrophil infiltration (Figure S3A). Similarly, the bacterial composition extracted from $P$. aeruginosa strains induced neutrophil accumulation but no hemorrhage (Figure S3B). Based on these evidences, we speculate the virulence factors are most likely proteins, especially exotoxin A or proteinases.

To avoid pneumothorax, we reduced the exoproducts to $1 / 4(1 \mathrm{mg}$ protein/ml) of the concentration used in Figure 3A. Mice were sacrificed after $24 \mathrm{~h}$. Still, heavy bleeding and hyaline membrane occurred in all animals. The severity was different, judged from gross appearance of left lungs (Figure 3B). Exoproducts of $\mathrm{Pa} 4$ instilled lung had also induced 
subcapsular liver hemorrhage. A combination of proteinase inhibitor cocktail with EDTA added largely alleviated the injury. ALI score shows clearly that exoproducts from $\mathrm{Pa}$ 4, 5, 6 are the strongest in induce lung injury, while Pa 3 is the weakest (Figure $3 \mathrm{C}$ ). This tendency is in comply with the virulence of the corresponding bacteria (Figure 3D).

To find which pulmonary cell is the main victim, TUNEL labeling were used to stain both $P$. aeruginosa bacteria and exoproducts damaged lungs (Figure 3D). To our surprise, although both caused severe DAD, the exoproducts only induced $5.19 \%$ pulmonary cells apoptosis compared to the $71.7 \%$ cellular apoptosis rate caused by live bacteria. This means cell damage is not essential for the appearance of DAD.

Consequently, we infer the hemorrhagic lung injury may have resulted from the disturbance of hemostasis and destruction of extracellular matrix. We then examined the proteolysis ability of exoproducts to the two key proteins in clotting process: fibrinogen and thrombin. Figure 3E shows the fibrinogenolytic activity of the exoproducts compared with porcine elastase. The Aa and $B \beta$ chains of fibrinogen were hydrolyzed by all exoproducts in $1 \mathrm{~h}$. However, Pa 4-6 exoproducts totally degraded the $y$ chain of fibrinogen as well. The proteolysis was suppressed by EDTA, and to a great extent by matrix metalloprotease inhibitor (Ilomastat), but was not suppressed by proteinase inhibitors, suggesting the virulence effectors are most likely matrix metalloproteases. The freshly formed fibrin clots were also digested by exoproducts (data not shown).

Thrombin degradation assay exhibited a similar result (Figure 3F). However, the EDTA usage was much higher due to the $\mathrm{Ca}^{2+}$ ions contained in the commercially acquired thrombin. 
Collagen and elastin are the major protein composition of pulmonary matrix. They provide mechanical stability and elastic recoil, which are essential for physiological lung function and initiation of biochemical signals in extrinsic blood coagulation. To visualize the degradation of collagen, gelatin zymography method were used (Figure 3G). All exoproducts from $P$. aeruginosa exhibited bright bands on zymography, especially Pa 4, 5 and 6. Distinguished from the rest, $\mathrm{Pa} 2$ exoproducts showed a major bright band near $80 \mathrm{kDa}$, whereas the other exoproducts manifested mainly at the same level at $120 \mathrm{kDa}$. The activity can be mostly inhibited by EDTA.

We then measured the elastin lytic activity of each exoproducts using elastin-Congo red method (Table 4). All exoproducts have elastinolytic activity, which level has a tendency to be positively related to the ALI score of exoproducts and the virulence of the corresponding $P$. aeruginosa strains. The results reveal the exoproducts from $P$. aeruginosa are powerful in destroying pulmonary structural compositions, especially $\mathrm{Pa} 4,5$ and 6 .

\section{Identification and purification of virulent protein from exoproducts}

Exoproducts from $8 P$. aeruginosa strains were subjected to SDS-PAGE to analyze the secretory proteome. The gel was stained by Coomassie blue (Figure 4A). Protein bands of interest were excised carefully and subjected to LC-MS/MS analysis. The intensive band appeared at the molecular mass of $70 \mathrm{kDa}$ from less virulent strains first caught our attention, which however were found to be catalase or acetylated catalase. Then we identified the most abundant protein secreted by hypervirulent strains $\mathrm{Pa} 4,5$ and 6 (at $35 \mathrm{kDa}$ ) as LasB elastase. Further analysis showed relative LasB expression in exoproducts of $P$. aeruginosa strains 
resembles their lung damage ability (Figure 4B).

As it was shown in gelatin zymography, $\mathrm{Pa} 2$ presented a major band at $80 \mathrm{kDa}$, different to others. However, LC-MS/MS analysis of the band found no other proteases than LasB (Figure 4E). Meanwhile, no LasA was detected from $\mathrm{Pa} 2$ or $\mathrm{Pa} 4$.

Taken together the results of LC-MS/MS and gelatin zymography, we selected strain $\mathrm{Pa} 4$ to culture and harvest LasB. LasB was separated from the exoproducts by DEAE-cellulose. As shown in the elution profile (Figure 4C), the only active enzyme was eluted between $0.1 \mathrm{M}$ to $0.25 \mathrm{M} \mathrm{NaCl}$ (fractions 5-15). Fraction 10 was collected and the protein contained was concentrated to $2 \mathrm{mg} / \mathrm{ml}$. The purity was verified by SDS-PAGE as a single band at $35 \mathrm{kDa}$, and confirmed to be LasB elastase (Figure 4D). Purified LasB exhibited an increase in elastase specific activity measured by elastin-Congo red assay (Table 4).

\section{LasB elastase induced hemorrhagic acute lung injury through degradation of alveolar} matrix and key proteins in coagulation cascade.

To confirm LasB is the effector in $P$. aeruginosa exoproducts provoked acute lung injury, $30 \mu \mathrm{l}$ of LasB ranging from 0.005 to $2 \mu \mathrm{g} / \mu \mathrm{l}$ were tested in the left lungs of mice. Significant DAD, hemorrhage, hyaline membrane and emphysematous alveolar destruction were clearly formed by LasB ranging from $0.6 \mu \mathrm{g}$ to $6 \mu \mathrm{g}$ (Figure $5 \mathrm{~A}$ ). The injury could be suppressed by EDTA, MMP and EDTA plus low concentration of protease inhibitor cocktail (Figure 5B). However, the damage was aggravated by high concentration of protease inhibitor cocktail, which further tests found the cocktail itself, when instilled in high concentration, could cause rapid death in 
mice without alveolar tissue damage. We don't know why yet. Meanwhile, we found the LasB dosage higher than $6 \mu$ g caused tension pneumothorax and death in $70 \%$ of the mice $(n=10)$.

Same as the exoproducts, TUNEL stain detected no significant difference in cellular apoptosis between LasB damaged lungs and intact lungs (Figure $5 \mathrm{C}$ ), meaning LasB has little cytotoxicity to pulmonary cells in vivo. Also, THP-1 cytotoxicity assay found purified LasB was not virulent to cells, unlike the bacteria (Figure 5C).

However, LasB exhibited strong ability to degrade key enzymes in clotting process. After incubated at $37^{\circ} \mathrm{C}$ for 1 hour, $12.5 \mu \mathrm{g} / \mathrm{ml}$ LasB hydrolyzed the $4 \mathrm{mg} / \mathrm{ml}$ fibrinogen totally and the $2 \mathrm{mg} / \mathrm{ml}$ thrombin partially (Figure 5E). EDTA and Ilnomastat both suppressed the process. On the contrary, TLCK exerted no inhibitory effect. This helped to rule out the trace of Protease IV. Purified LasB appeared as a single clear band at molecular weight of $120 \mathrm{kDa}$ on gelatin zymography, proved its ability to cleavage collagen. Interestingly, after been incubated with EDTA, it only left a vague band near $35 \mathrm{kDa}$ (Figure 5F).

From the fibrinogen degradation assay, we have noticed that purified LasB as well as $\mathrm{Pa} 4$, 5, 6 exoproducts caused a thoroughly fibrinogen degradation. We speculate this might lead to an increase in plasma fibrinogen degradation products (FDP) and D-Dimer. We thus added LasB to human blood drawn from health donors. Results are shown in Figure $5 \mathrm{H}$. LasB had drastically increased FDP and D-Dimer level and elongated thrombin time (TT), causing DIC like coagulopathy in vitro. In addition, it didn't change the indicators of endogenous coagulation pathway such as APTT, PT INR, nor affected the activity of antithrombin (AT) or plasminogen 
(PA). Also, we studied on if it degrades fibrinogen in vivo by injecting LasB intravenously to rats $(2 \mathrm{mg} / \mathrm{kg})$. Significant decline of fibrinogen was observed within $1 \mathrm{~h}$ (Figure $5 \mathrm{G}$ ). However, no difference detected in thrombin time in vivo.

\section{Discussion}

Pneumonia is the major risk factor of ALI/ARDS. In most patients suspected or diagnosed of pneumonia, several bacteria could be found coexisting in the sputum. In this study, we examined the ability of these pathogenic bacteria isolated from patients to induce ALI in mice. Among 7 major species, gram-positive bacteria didn't cause obvious alveolar injury, even the hypervirulent ones. In comparison, gram-negative bacteria are much more deleterious in lung. $P$. aeruginosa was found to be the most virulent, inducing hemorrhagic diffused alveolar damage, pink frothy sputum and death in animals within a few hours. We found the ALI score is positively related to their LasB elastase level. Purified LasB per se sufficiently induced diffused alveolar damage and tissue bleeding in mice. High dosage of LasB could even cause spontaneous tension pneumothorax, bullae formation and death of mice in merely 3 hours. However, our results show LasB exhibited little cytotoxicity to pulmonary cells. Further exploration validated this LasB metalloprotease is extremely efficient to hydrolysis the main component of lung structure and key proteins in clotting process such as collagen, elastin, fibrinogen, fibrin and thrombin. Collectively, our results suggest that by inducing matrix degradation and coagulopathy, LasB is the most important virulence effector of clinical $P$. aeruginosa isolates in lung infection.

$P$. aeruginosa is an opportunistic pathogen ubiquitously presenting in the environment. 
Despite the significant changes of microbial spectrum of infections in intensive care, $P$.

aeruginosa has held a nearly unchanged position in the rank order of pathogens causing

ICU-related infections for more than 4 decades[19]. Multiple resistance mechanisms enabled

this microorganism to escape a wide range of antibiotics. Multidrug-resistant (MDR) $P$.

aeruginosa has aroused serious concerns over its close relation to high mortality of patients

with hospital-acquired and ventilator-associated pneumonia (VAP) in the ICUs[20].

Among the arsenal of virulence factors armed by $P$. aeruginosa, type III secretion system

(T3SS) is characterized as the major one responsible for alveolar epithelial injury in patients.

T3SS could directly inject four toxins: ExoU, ExoT, ExoS and ExoY into the cytosol of target

eukaryotic cells when in contact. Strains of $P$. aeruginosa possessing the exoU gene are

considered most deleterious [21]. However, among the 8 strains we collected, exoU+

genotype $\mathrm{Pa} 2$ is not as virulent as exoU- genotype $\mathrm{Pa} 4, \mathrm{~Pa} 5$ and $\mathrm{Pa} 6$ in causing

hemorrhagic ALI, indicating that T3SS is probably not as important in ALI/ARDS pathogenesis.

Exoproducts of $P$. aeruginosa are composed of many cell-associated and extracellular

virulence factors, such as LPS, flagellin, proteases, exotoxins, pyocyanin, siderophores,

hemolysins, and phospholipases[22]. Among them, we found ALI is mainly caused by

proteases. However, $P$. aeruginosa secrets at least six proteases including alkaline protease

(AprA), elastase A (LasA), elastase B (LasB), large exoprotease A (LepA), protease IV (PIV)

and Pseudomonas small protease (PASP). Many researches had found $P$. aeruginosa

proteases caused severe lung hemorrhage and injury in animals, however, the effect was not

specifically attributed to the LasB elastase, as opposed to LasA elastase or other proteases 
[23-27]. Moreover, most studies investigated the role of LasB in lung infection used defined deletion or insertion mutants of the LasB gene, or used broad-spectrum metalloprotease inhibitors alternatively, which may not be assigned unequivocally to the impact of LasB [28-30]. Instead, our team successfully purified LasB elastase from a highly lung destructive $P$. aeruginosa strain and elucidated the direct causative effect of LasB in both vitro and vivo.

Further more, we ruled out the contribution of LasA, LepA, PASP and alkaline protease in ALI due to the fact the LC-MS/MS detected no LasA elastase, LepA or PASP from strain Pa 4 exoproducts, while both SDS-PAGE and zymography of purified LasB showed no bands at the molecular weight fits to alkaline protease as reported[17]. We applied TLCK inhibition assay to further ruled out the participation of PIV. Our study strongly suggest LasB is the most important lung injury protease secreted from $P$. aeruginosa.

$P$. aeruginosa LasB elastase (pseudolysin) is a neutral metalloprotease with both proteolytic and elastolytic activities that could be inhibited by metal chelators such as EDTA or MMP inhibitors. LasB has been shown to degrade a vast array of host proteins including structural components such as elastin/ collagen/laminin, immune factors like $\lg \mathrm{A} / \lg \mathrm{G} / \mathrm{TNF}$ - $\mathrm{a} /$ IFN-y/IL-2/IL-6/a1-antiprotease and proteins important in coagulation function like fibrin/fibrinogen/thrombin[28]. Likewise, we have validated that the important protein components in lung and clotting process can be efficiently hydrolyzed by LasB.

We also tested the commercially available recombinant LasB protein produced by $E$. coli (30R-3401, Fitzgerald) in pilot studies, however, it showed no elastolysis in vitro nor lung destruction in vivo, indicating that the toxicity of LasB mainly attributes to its activity than 
immunogenicity (data not shown).

Even though LasB is sufficient to provoke all necessary histopathological change identical to DAD found in ALI/ARDS, it didn't show obvious cytotoxicity to THP-1 cells or to pulmonary cells. Jose at al. had reported similar results, that moderate LasB protease is nontoxic to Hep2 cells[31]. However, in real $P$. aeruginosa infection, not only DAD, but also extended cell apoptosis were observed. Since both LasB and exoproducts have shown no obvious cytotoxicity, we suppose the apoptosis might be caused by the other virulent factors such as T3SS and T6SS, which are highly efficient, but requires direct bacteria-to-cell contact[21]. Also, we found the most abundant protein secreted by less virulent $P$. aeruginosa strains is catalase, which probably explains their clinical prevalence, for catalase offers strong protection over nutrient-starved and biofilm bacteria from $\mathrm{H}_{2} \mathrm{O}_{2}$ and antibiotic-mediated killing[32].

The exoproducts of $\mathrm{Pa} 2$ manifested a major band near $80 \mathrm{kDa}$ compared with other exoproducts (near $120 \mathrm{kDa}$ ) on gelatin zymography, however, the LC-MS/MS analysis of the band showed no other proteases than the neutral metalloproteinase LasB. This is in compliance with the report from Marquart et al.[33]. We infer the Pa 2 produced LasB might have some difference in polymer conformation since the aggregation of LasB monomers to different polymer forms on zymograms is commonly found[34].

FDPs and D-Dimers are the products of degraded fibrinogen or fibrin. As LasB exhibited strong ability to decompose fibrinogen, we wondered if it would raise the level of FDP and D-Dimer. Incubation of LasB with heathy donors' blood confirmed our hypothesis, for only 35 mins, it significantly decreased fibrinogen level and drastically increased both FDP and 
D-Dimer level, causing DIC-like clotting disfunction. Interestingly, LasB didn't disrupt anticoagulant process. This may aggravate the coagulopathy even more, and helped to explain the heavy bleeding in lung. LasB administrated intravenously in rat has decreased fibrinogen level in vivo as well. Whereas, thrombin time elongation was not found. We are not sure if this was caused by the strong compensatory capacity of the SD rats or by some other reasons yet. More exploration will focus on this matter in the future.

In this study, we isolated 8 clinical strains of $P$. aeruginosa, they are different in many aspects such as morphology, pigment production or T3SS genes. LasB production is the one of the few common features they share and correlates in proportion with their virulence in lung. Not only $P$. aeruginosa, a large variety of microorganisms secret extracellular proteinases too, like collagenase from Clostridium histolyticum and thermolysin from Bacillus thermoproteolyticus [35]. S. aureus, S. agalactiae and S. pneumoniae are known for their hyaluronidase production [36]. These enzymes enabled bacteria with extraordinary power to break barriers and spread $[35,37]$. However, due limited time and resource, we haven't been able to test and identify the virulence factor of every clinical isolate. Also, as our research focused on the major respiratory tract isolates and some subtypes in China, it is not known whether our results are fully applicable to other areas, where bacterial prevalence pattern may be quite different. Further studies are needed.

The research of Zupetic. $\mathrm{J}$ and colleges have showed that $P$. aeruginosa elastase activity was common in ICU respiratory isolates representing $75 \%$ of samples and was associated with increased 30-day mortality[38]. In this study, we demonstrated that $P$. aeruginosa is the 
queen of pulmonary pathogens. Among all its exoproducts, LasB per se is sufficient and necessary to elicit hemorrhagic diffused alveolar damage in animals. Monitoring LasB levels might be helpful in predicting the outcome of ALI/ARDS patients.

\section{Acknowledgements}

We would like to thank Dr. Jingxian Liu (Division of Medical Microbiology, Department of

Clinical Laboratory, Xinhua Hospital) as well as Professor Yong Zhang (Department of

Immunology, SJTUSM) and Professor Min Wang (Department of Histology and Embryology,

SJTUSM) for their skilled advice and assistance;

Reference

1. Fan, E., D. Brodie, and A.S. Slutsky, Acute Respiratory Distress Syndrome: Advances in Diagnosis and Treatment. Jama, 2018. 319(7): p. 698-710.

2. Silva, P.L., P. Pelosi, and P.R.M. Rocco, Personalized pharmacological therapy for ARDS: a light at the end of the tunnel. Expert Opin Investig Drugs, 2020. 29(1): p. 49-61.

3. Bellani, G., et al., Epidemiology, Patterns of Care, and Mortality for Patients With Acute Respiratory Distress Syndrome in Intensive Care Units in 50 Countries. Jama, 2016. 315(8): p. 788-800.

4. Tanner, J.R. and R.A. Kingsley, Evolution of Salmonella within Hosts. Trends Microbiol, 2018. 26(12): p. 986-998. 
5. Defraine, V., M. Fauvart, and J. Michiels, Fighting bacterial persistence: Current and emerging anti-persister strategies and therapeutics. Drug Resist Updat, 2018. 38: p. $12-26$.

6. Bauer, T.T., et al., Acute respiratory distress syndrome and pneumonia: a comprehensive review of clinical data. Clin Infect Dis, 2006. 43(6): p. 748-56.

7. Cepas, V. and S.M. Soto, Relationship between Virulence and Resistance among Gram-Negative Bacteria. Antibiotics (Basel), 2020. 9(10).

8. Maunders, E.A., et al., Global reprogramming of virulence and antibiotic resistance in Pseudomonas aeruginosa by a single nucleotide polymorphism in elongation factor, fusA1. J Biol Chem, 2020. 295(48): p. 16411-16426.

9. Duan, Y., et al., Antibiotic Resistance and Virulence of Extraintestinal Pathogenic Escherichia coli (ExPEC) Vary According to Molecular Types. Front Microbiol, 2020.

11: p. 598305.

10. Rawson, T.M., et al., Bacterial and Fungal Coinfection in Individuals With Coronavirus: A Rapid Review To Support COVID-19 Antimicrobial Prescribing. Clin Infect Dis, 2020. 71(9): p. 2459-2468.

11. Bakaletz, L.O., Viral-bacterial co-infections in the respiratory tract. Curr Opin Microbiol, 2017. 35: p. 30-35.

12. Hu, F., et al., Resistance reported from China antimicrobial surveillance network 
(CHINET) in 2018. Eur J Clin Microbiol Infect Dis, 2019. 38(12): p. 2275-2281.

13. Matute-Bello, G., et al., An official American Thoracic Society workshop report:

features and measurements of experimental acute lung injury in animals. Am J Respir

Cell Mol Biol, 2011. 44(5): p. 725-38.

14. Hsia, C.C., et al., An official research policy statement of the American Thoracic Society/European Respiratory Society: standards for quantitative assessment of lung structure. Am J Respir Crit Care Med, 2010. 181(4): p. 394-418.

15. Curran, B., et al., Development of a multilocus sequence typing scheme for the opportunistic pathogen Pseudomonas aeruginosa. J Clin Microbiol, 2004. 42(12): p. $5644-9$.

16. Jolley, K.A., J.E. Bray, and M.C.J. Maiden, Open-access bacterial population genomics: BIGSdb software, the PubMLST.org website and their applications. Wellcome Open Res, 2018. 3: p. 124.

17. Kessler, E. and M. Safrin, Elastinolytic and proteolytic enzymes. Methods Mol Biol, 2014. 1149: p. 135-69.

18. Wiśniewski, J.R., et al., Universal sample preparation method for proteome analysis. Nat Methods, 2009. 6(5): p. 359-62.

19. Trautmann, M., P.M. Lepper, and M. Haller, Ecology of Pseudomonas aeruginosa in the intensive care unit and the evolving role of water outlets as a reservoir of the 
organism. Am J Infect Control, 2005. 33(5 Suppl 1): p. S41-9.

20. Botelho, J., F. Grosso, and L. Peixe, Antibiotic resistance in Pseudomonas aeruginosa - Mechanisms, epidemiology and evolution. Drug Resist Updat, 2019. 44: p. 100640.

21. Sawa, T., et al., Association between Pseudomonas aeruginosa type III secretion, antibiotic resistance, and clinical outcome: a review. Crit Care, 2014. 18(6): p. 668.

22. Sauvage, S. and J. Hardouin, Exoproteomics for Better Understanding Pseudomonas aeruginosa Virulence. Toxins (Basel), 2020. 12(9).

23. Meinke, G., et al., In Vivo Studies with the Partially Purified Protease (Elastase) from Pseudomonas aeruginosa. Infect Immun, 1970. 2(5): p. 583-9.

24. Elsen, S., et al., A type III secretion negative clinical strain of Pseudomonas aeruginosa employs a two-partner secreted exolysin to induce hemorrhagic pneumonia. Cell Host Microbe, 2014. 15(2): p. 164-76.

25. Williams, J.C., et al., Acute lung injury induced by Pseudomonas aeruginosa elastase in hamsters. Exp Lung Res, 1992. 18(1): p. 155-71.

26. Gray, L. and A. Kreger, Microscopic characterization of rabbit lung damage produced by Pseudomonas aeruginosa proteases. Infect Immun, 1979. 23(1): p. 150-9.

27. Wolz, C., et al., Pseudomonas aeruginosa LasB mutant constructed by insertional mutagenesis reveals elastolytic activity due to alkaline proteinase and the Las $A$ fragment. Mol Microbiol, 1991. 5(9): p. 2125-31. 
28. Everett, M.J. and D.T. Davies, Pseudomonas aeruginosa elastase (LasB) as a therapeutic target. Drug Discov Today, 2021.

29. Qu, Y., et al., Thrombospondin-1 protects against pathogen-induced lung injury by limiting extracellular matrix proteolysis. JCI Insight, 2018. 3(3).

30. Cowell, B.A., et al., Mutation of lasA and lasB reduces Pseudomonas aeruginosa invasion of epithelial cells. Microbiology (Reading), 2003. 149(Pt 8): p. 2291-2299.

31. Jose, D., et al., Purification and characterization of highly active LasB protease from pseudomonas aeruginosa MCCB 123. Indian Journal of Experimental Biology, 2017. 55: p. 303-310.

32. Khakimova, M., et al., The stringent response controls catalases in Pseudomonas aeruginosa and is required for hydrogen peroxide and antibiotic tolerance. J Bacteriol, 2013. 195(9): p. 2011-20.

33. Marquart, M.E., et al., Identification of a novel secreted protease from Pseudomonas aeruginosa that causes corneal erosions. Invest Ophthalmol Vis Sci, 2005. 46(10): p. 3761-8.

34. Caballero, A.R., et al., Pseudomonas aeruginosa protease IV enzyme assays and comparison to other Pseudomonas proteases. Anal Biochem, 2001. 290(2): p. 330-7.

35. Duarte, A.S., A. Correia, and A.C. Esteves, Bacterial collagenases - A review. Crit Rev Microbiol, 2016. 42(1): p. 106-26. 
bioRxiv preprint doi: https://doi.org/10.1101/2021.05.15.444319; this version posted May 15, 2021. The copyright holder for this preprint (which

was not certified by peer review) is the author/funder, who has granted bioRxiv a license to display the preprint in perpetuity. It is made available under aCC-BY-NC-ND 4.0 International license.

36. Hynes, W.L. and S.L. Walton, Hyaluronidases of Gram-positive bacteria. FEMS

Microbiol Lett, 2000. 183(2): p. 201-7.

37. Matsumoto, K., Role of bacterial proteases in pseudomonal and serratial keratitis. Biol

Chem, 2004. 385(11): p. 1007-16.

38. Zupetic, J., et al., Elastase Activity from Pseudomonas aeruginosa Respiratory

Isolates and ICU Mortality. Chest, 2021. 


\section{Tables}

Table 1. Virulence genes analysis in clinical isolates of Pseudomonas aeruginosa

\begin{tabular}{llllllllll}
\hline & & \multicolumn{7}{c}{ PCR results } \\
\cline { 2 - 8 } Gene & Protein & Pa 1 & $\mathrm{~Pa} 2$ & $\mathrm{~Pa} 3$ & $\mathrm{~Pa} 4^{*}$ & $\mathrm{~Pa} 5^{*}$ & $\mathrm{~Pa} \mathrm{6}$ & $\mathrm{Pa} \mathrm{M}$ & $\mathrm{Pa} \mathrm{J}$ \\
\hline aprA & Alkaline protease & + & + & + & + & + & + & + & + \\
toxA & Exotoxin A & + & + & + & + & + & + & + & + \\
lasB & Elastase (LasB) & + & + & + & + & + & + & + & + \\
lasA & Elastase (LasA) & + & + & + & + & + & + & + & + \\
plcH & Phospholipase C & + & + & + & + & + & + & + & + \\
prpL & Protease IV & + & + & + & + & + & + & + & + \\
exoS & ExoS & + & $(-)$ & + & + & + & + & + & + \\
exoU & ExoU & $(-)$ & + & $(-)$ & $(-)$ & $(-)$ & $(-)$ & + & $(-)$ \\
exoT & ExoT & + & + & + & + & + & + & + & + \\
exoY & ExoY & + & + & + & + & + & + & + & + \\
lepA & large extracellular & + & + & + & + & + & + & + & + \\
& protease & & & & & & & & \\
phzS & flavin-dependent & + & $(-)$ & $(-)$ & $(-)$ & $(-)$ & $(-)$ & $(-)$ & + \\
& hydroxylase & & & & & & & & \\
rhIR & QS & + & + & + & + & + & + & + & + \\
mucA & QS & + & + & + & + & + & + & + & + \\
algR & QS & + & + & + & + & + & + & + & + \\
fliC & flagellar filament & + & $(-)$ & + & + & $(-)$ & $(-)$ & + & $(-)$ \\
& structural protein & & & & & & & & \\
\hline
\end{tabular}

QS, quorum sensing.

+ , positive.

$(-)$, negative.

* high virulence strain 
bioRxiv preprint doi: https://doi.org/10.1101/2021.05.15.444319; this version posted May 15, 2021. The copyright holder for this preprint (which

was not certified by peer review) is the author/funder, who has granted bioRxiv a license to display the preprint in perpetuity. It is made available under aCC-BY-NC-ND 4.0 International license.

Table 2. Drug resistance and other characters of $P$. aeruginosa isolates

\begin{tabular}{|c|c|c|c|c|c|c|c|c|}
\hline & $\mathrm{Pa} 1$ & $\mathrm{~Pa} 2$ & $\mathrm{~Pa} 3$ & $\mathrm{~Pa} 4$ & $\mathrm{~Pa} 5$ & $\mathrm{~Pa} 6$ & $\mathrm{~Pa} \mathrm{M}$ & $\mathrm{PaJ}$ \\
\hline \multicolumn{9}{|l|}{ Antimicrobial agents } \\
\hline $\begin{array}{l}\text { Cefoperazone-sul } \\
\text { bactam }\end{array}$ & $S$ & $\mathrm{R}$ & $S$ & $S$ & $S$ & $S$ & $S$ & 1 \\
\hline Meropenem & $S$ & $\mathrm{R}$ & $S$ & $S$ & $S$ & $S$ & $S$ & $S$ \\
\hline Levofloxacin & $\mathrm{R}$ & $\mathrm{R}$ & $S$ & $S$ & $S$ & $S$ & $S$ & 1 \\
\hline \multicolumn{9}{|l|}{ Pigment producing } \\
\hline Pyocyanin & + & $(-)$ & $(-)$ & $(-)$ & $(-)$ & $(-)$ & $(-)$ & + \\
\hline
\end{tabular}


bioRxiv preprint doi: https://doi.org/10.1101/2021.05.15.444319; this version posted May 15, 2021. The copyright holder for this preprint (which

was not certified by peer review) is the author/funder, who has granted bioRxiv a license to display the preprint in perpetuity. It is made available under aCC-BY-NC-ND 4.0 International license.

Table 3. Multilocus sequence typing of clinical isolates of $\boldsymbol{P}$. aeruginosa

\begin{tabular}{lcccccccc}
\hline & & \multicolumn{7}{c}{ Allele types } \\
\cline { 3 - 9 } & ST & acsA & aroE & guaA & mutL & nuoD & ppsA & trpE \\
\hline Pa 1 & 3405 & 17 & 5 & 5 & 4 & 137 & 4 & 3 \\
Pa 2 & 1076 & 5 & 4 & 57 & 62 & 1 & 1 & 26 \\
Pa 3 & $3580^{*}$ & 15 & 5 & 36 & 11 & 27 & $189^{*}$ & 2 \\
Pa 4 & 3118 & 6 & 5 & 11 & 11 & 4 & 4 & 193 \\
Pa 5 & $3576^{*}$ & 5 & 4 & 57 & 62 & 4 & 1 & 26 \\
Pa 6 & $3577^{*}$ & 1 & 178 & 26 & 3 & 1 & 4 & 34 \\
Pa M & $3578^{*}$ & 6 & 5 & 11 & 4 & 4 & 3 & 3 \\
Pa J & 871 & 16 & 3 & 1 & 5 & 1 & 55 & 61 \\
\hline
\end{tabular}

ST, sequence type.

* newly found in this research. 
bioRxiv preprint doi: https://doi.org/10.1101/2021.05.15.444319; this version posted May 15, 2021. The copyright holder for this preprint (which

was not certified by peer review) is the author/funder, who has granted bioRxiv a license to display the preprint in perpetuity. It is made available under aCC-BY-NC-ND 4.0 International license.

Table 4. Elastase activity of purified LasB and exoproducts measured by Elastin-Congo assay

\begin{tabular}{llllllllll}
$\begin{array}{l}\text { Purified } \\
\text { LasB }\end{array}$ & $\begin{array}{l}\text { Crude } \\
\text { enzyme }\end{array}$ & Pa 1 & Pa 2 & Pa 3 & Pa 4 & Pa 5 & Pa 6 & Pa M & Pa J \\
\hline 90.96 & 4.225 & 1.59 & 3.23 & 0.57 & 12.5 & 12.6 & 15.1 & 3.33 & 2.18 \\
\hline
\end{tabular}


Table S1. Primer sequences used in PCR for detecting virulence genes

\begin{tabular}{|c|c|c|c|}
\hline GN & & Sequence & product length $(\mathrm{bp})$ \\
\hline \multirow[t]{2}{*}{ toxA } & $\mathrm{F}$ & 5' - CTGCGCGGGTCTATGTGCC & 270 \\
\hline & $\mathrm{R}$ & 5' - GATGCTGGACGGGTCGAG & \\
\hline \multirow[t]{2}{*}{ lasB } & $\mathrm{F}$ & 5' - GCGAATTGGCCAACAGGTAG & 544 \\
\hline & $\mathrm{R}$ & 5' - CCGACCAACACCTACAAGCA & \\
\hline \multirow[t]{2}{*}{ las $A$} & $\mathrm{~F}$ & 5' - GCAGCACAAAAGATCCC & 1075 \\
\hline & $\mathrm{R}$ & 5' - GAAATGCAGGTGCGGTC & \\
\hline \multirow[t]{2}{*}{ aprA } & $\mathrm{F}$ & 5' - ATGTACCGGATGCGCTCAAG & 506 \\
\hline & $\mathrm{R}$ & 5' - CGCCTTCTCGTTGAGGTTGA & \\
\hline \multirow[t]{2}{*}{ exos } & $\mathrm{F}$ & 5' - GAGAGATAGCCGTCGTCGTG & 355 \\
\hline & $\mathrm{R}$ & 5' - AGAGCGAGGTCAGCAGAGTA & \\
\hline \multirow[t]{2}{*}{ exou } & $\mathrm{F}$ & 5' - GCTGAAGCTGTTCCAACACA & 466 \\
\hline & $\mathrm{R}$ & 5' - CTGGTACGGCTGATCACTCA & \\
\hline \multirow[t]{2}{*}{ exoT } & $\mathrm{F}$ & 5' - CAGCATGTACTCAGCGCAAG & 515 \\
\hline & $\mathrm{R}$ & 5' - AACAGGGTGGTTATCGTGCC & \\
\hline \multirow[t]{2}{*}{ exoY } & $\mathrm{F}$ & 5' - CCCTGCCATAGAATCCGTCC & 525 \\
\hline & $\mathrm{R}$ & 5' - TCTCGGTGAAGGGGAAAAGC & \\
\hline \multirow[t]{2}{*}{ rhIR } & $\mathrm{F}$ & 5' - TGCTCAGGATGATGGCGATT & 507 \\
\hline & $\mathrm{R}$ & 5' - TGGGCTTCGATTACTACGCC & \\
\hline \multirow[t]{2}{*}{ mucA } & $\mathrm{F}$ & 5' - GGAAACTCTGTCCGCTGTGA & 522 \\
\hline & $\mathrm{R}$ & 5' - СТСTCTGTACCACTGACGGC & \\
\hline \multirow[t]{2}{*}{$\operatorname{alg} R$} & $\mathrm{~F}$ & 5' - ACGTACTTGTGGTCGGCAAT & 450 \\
\hline & $\mathrm{R}$ & 5' - ATTGGTAGGGCAACTGGACG & \\
\hline \multirow[t]{2}{*}{ lepA } & $\mathrm{F}$ & 5' - GCGGGTGAAAGAGGAAATCG & 567 \\
\hline & $\mathrm{R}$ & 5' - CTTTCCGGCTCGTATTGCAG & \\
\hline \multirow[t]{2}{*}{ phzS } & $\mathrm{F}$ & 5' - CTGGTCGCCTATCCGATCTC & 507 \\
\hline & $\mathrm{R}$ & 5' - GCTCTTCTCGGTCTTCGGTC & \\
\hline \multirow[t]{2}{*}{ plcH } & $\mathrm{F}$ & 5' - CCAGGGCGAGATGTTTTCCT & 528 \\
\hline & $\mathrm{R}$ & 5' - CTCGCCTGGTTCAGGAACTT & \\
\hline
\end{tabular}


bioRxiv preprint doi: https://doi.org/10.1101/2021.05.15.444319; this version posted May 15, 2021. The copyright holder for this preprint (which

was not certified by peer review) is the author/funder, who has granted bioRxiv a license to display the preprint in perpetuity. It is made available under aCC-BY-NC-ND 4.0 International license.

flic

F 5' - CTGACCATCACCTCCGCTAC

443

R 5' - CGAGCGTTGGTAGCGTTTTC

prpL

F 5' - TATGGATCCGCCGGCTACCGCGACGG

733

R 5' - GCCTCGAGGGGCGCGAAGTAGCGGGAGA 


\section{Figure legend}

Figure 1. Histological assessment of acute lung injury induced by representative bacteria

separated from clinical sputum. (A) Endotracheal intubation. Unilateral lung infiltration 4 hours after LPS instillation (3D CT reconstruction). (B) Hematoxylin and eosin (HE) stain of lung sections of gram-positive bacterial infection. S. aureus, S. agalactiae or S. pneumonia suspension was instilled unilaterally. Clean alveolar, no neutrophil infiltration noted in $24 \mathrm{~h}$. Coccus found in lung macrophages (black arrows). In high virulent gram-positive strains lung infection, large amount of coccus in the perivascular space (black arrowheads) or migrating into the vascular lumen $\left({ }^{*}\right)$ were seen (empty arrowheads), without alveolar damage. (C) HE stain of lung sections inoculated with gram-negative bacteria. Alveolar injury occurred in all Gbacteria infected lungs. K. pneumoniae: neutrophils in the alveolar wall and K. pneumoniae filled the alveolar space; $A$. baumannii: patchy neutrophil infiltration; $E$. coli: diffused neutrophil infiltration; P. aeruginosa: hemorrhage, hyaline membrane, vessel congestion, alveolar wall thickening and neutrophil infiltration. (D) Score of different bacteria induced ALI 24h post inoculation. 
Figure 2. ALI/ARDS induced by different strains of $P$. aeruginosa in mice. (A) Kaplan-Meyer survival curves for mice infected with different strains ( $n=10$ in each group). (B) Pink frothy sputum and bloody sputum from the nose and mouth of mice observed in Pa 2, 4, 5 and 6 infected group. (C) Representative histology finding in average $P$. aeruginosa lung infection: hemorrhage, neutrophil infiltration, hyaline membrane formation (arrowheads) and septal wall thickening in the alveolar. HE stain; (D) Representative histology finding in Pa 4, 5, 6 infected lungs: severe hemorrhage, alveolar structure destruction and bilateral infiltration. Bronchia lumen $\left(^{*}\right)$ inundated with red blood cells. Multiple hyaline membrane formation (arrowheads), diffused alveolar bleeding and neutrophil accumulation in less harmed control lung. HE stain; 
Figure 3. $P$. aeruginosa exoproducts induced hemorrhagic ALI in mice. (A) Diversified histology presentation caused by high concentration of exoproducts instillation. Bullae formation, severe bleeding and consolidation of the treated lung from mice died of tension pneumothorax, compared with emphysematous alveolar destruction and hemorrhage in survived mice. (B) Representative gross picture of $P$. aeruginosa exoproducts injured mice lung. Unilateral lung injury largely inhibited by protease inhibitor cocktail with EDTA added. Severe hyaline membrane, diffused alveolar damage, lung hemorrhage and subcapsular liver hemorrhage formed (arrowheads) in Pa 4 exoproducts intratracheal instilled mice. (C) ALI score of different $P$. aeruginosa strain exoproducts challenged lungs. (D) Representative TUNEL stain of $P$. aeruginosa bacteria/exoproducts challenged lungs. (E) Fibrinogen degradation effect of exoproducts. F, fibrinogen; Pe, porcine elastase $(F)$ Thrombin degradation effect of exoproducts. T: thrombin. (G) Gelatin zymography of exoproducts. 
bioRxiv preprint doi: https://doi.org/10.1101/2021.05.15.444319; this version posted May 15, 2021. The copyright holder for this preprint (which

was not certified by peer review) is the author/funder, who has granted bioRxiv a license to display the preprint in perpetuity. It is made available under aCC-BY-NC-ND 4.0 International license.

Figure 4. LasB elastase identification and purification. (A) SDS-PAGE of exoproducts from $8 P$. aeruginosa clinical isolates. (B) Relative LasB expression of 8 clinical isolates. (C) Elution profile of LasB protease through DEAE 52 cellulose column. RFU: relative fluorescence unit. (D)Verification of LasB purity by SDS-PAGE. 10, purified LasB (Fraction 10); 15, impurities (Fraction 15); 35, impurities (Fraction 35); CE, crude enzyme solution. (E) Amino acid sequence alignment of Las $\mathrm{B}$ from $\mathrm{Pa} 4, \mathrm{~Pa} 2$ and $\mathrm{PAO} 1$. 
Figure 5. LasB elastase induced hemorrhagic acute lung injury through degradation of alveolar matrix and key proteins in coagulation cascade. (A) HE stain of mice lung unilaterally instilled with $3 \mu \mathrm{g}$ LasB elastase. Apparent destruction to the whole left lung. Interwoven injury pattern of $\mathrm{DAD}$, hemorrhage, hyaline membrane, alveolar wall thickening, proteinaceous debris, neutrophils accumulation and multiple bullae formation (arrowheads); L, left; R, right. (B) Gross picture of lungs injured by LasB and effects of different inhibitors. LasB: LasB elastase, P-: protease inhibitor cocktail; EDTA: EDTA (25mM); B: 1/2 protease inhibitor cocktail + EDTA (12.5mM); MMP: llomastat (1mM). (C) TUNEL stain of LasB injured lungs. No apparent lung parenchymal cells apoptosis. (D) Cytotoxicity assay of LasB or Pa 4 bacteria to THP-1 cells. (E) Degradation of fibrinogen and thrombin with or without inhibitors in vitro. Fib, fibrinogen; 1: LasB + fibrinogen; 2: LasB + llomastat + fibrinogen; 3: LasB + TLCK + fibrinogen; 4: LasB + TLCK + fibrinogen; Thr, thrombin; 5: LasB + thrombin; 6: LasB + llomastat + thrombin; 7: LasB + TLCK + thrombin; 8: LasB + TLCK + thrombin; (F) The impact of LasB on coagulation function. LasB elastase and blood from healthy donors co-incubated for $35 \mathrm{~min}$, room temperature. (G) Clotting function in rats $1 \mathrm{~h}$ after injection of LasB elastase from tail vein. 
bioRxiv preprint doi: https://doi.org/10.1101/2021.05.15.444319; this version posted May 15, 2021. The copyright holder for this preprint (which

was not certified by peer review) is the author/funder, who has granted bioRxiv a license to display the preprint in perpetuity. It is made available under aCC-BY-NC-ND 4.0 International license.

Figure S1 (A) HE stain of lung tissue from the control lung (right lung) from both normal mice

(Control) and LPS unilateral instilled mice. No visible difference observed. (B) Tissue culture of

mice infected with highly virulent $S$. pneumoniae. All specimen contained high load of $S$.

pneumoniae. (C) Bronchoalveolar lavage fluid (BALF) smear and Gram's stain, from $K$.

pneumoniae infected mice. One leukocyte found, surrounded by countless thick capsular $K$.

pneumoniae. 
bioRxiv preprint doi: https://doi.org/10.1101/2021.05.15.444319; this version posted May 15, 2021. The copyright holder for this preprint (which

was not certified by peer review) is the author/funder, who has granted bioRxiv a license to display the preprint in perpetuity. It is made available under aCC-BY-NC-ND 4.0 International license.

Figure S2 (A) HE stain of strain Pa 3 instilled left lung and un-instilled right lung (control).

Bilateral perivascular bacteria proliferation found (black arrowhead). Heavier for the instilled

lung. (B) Morphology of 8 P. aeruginosa strains cultured on sheep blood agar plates. 
bioRxiv preprint doi: https://doi.org/10.1101/2021.05.15.444319; this version posted May 15, 2021. The copyright holder for this preprint (which

was not certified by peer review) is the author/funder, who has granted bioRxiv a license to display the preprint in perpetuity. It is made available under aCC-BY-NC-ND 4.0 International license.

Figure S3 (A) Heated $P$. aeruginosa exoproducts $\left(10 \mathrm{~min}, 100^{\circ} \mathrm{C}\right)$ induced neutrophil

accumulation, but didn't induce hemorrhage or alveolar destruction. (B) P. aeruginosa

bacterial composition induced mild neutrophil infiltration but no other histological change. HE

stain. 
bioRxiv preprint doi: https://doi.org/10.1101/2021.05.15.444319; this version posted May 15, 2021. The copyright holder for this preprint (which

was not certified by peer review) is the author/funder, who has granted bioRxiv a license to display the preprint in perpetuity. It is made available under aCC-BY-NC-ND 4.0 International license.

\section{Figures}

Figure 1

A

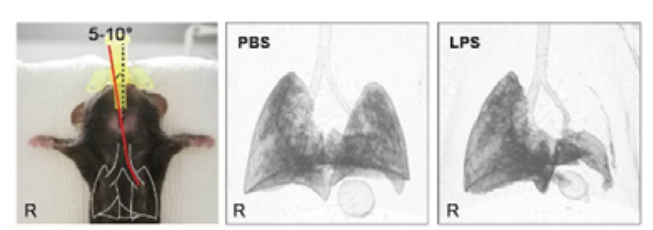

B Staphylococcus aureus

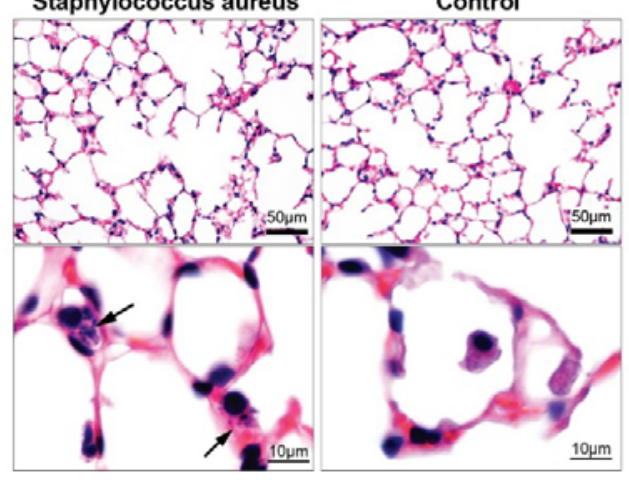

Highly virulent
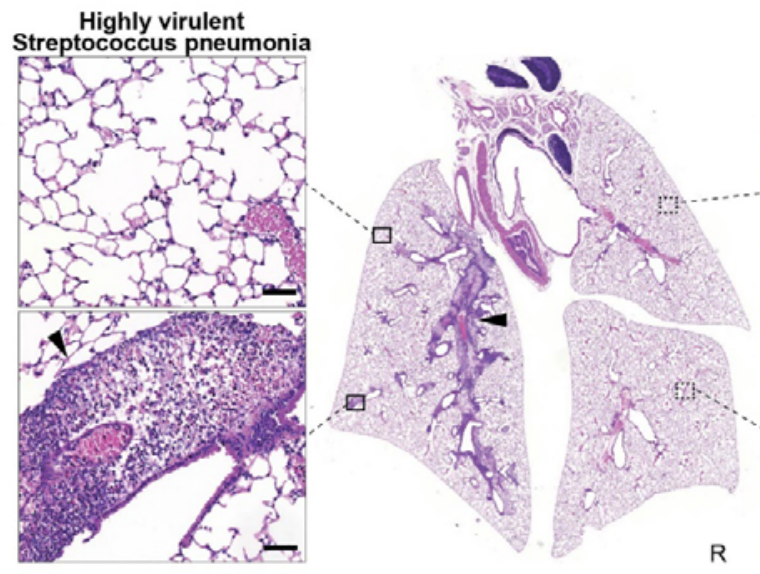

D

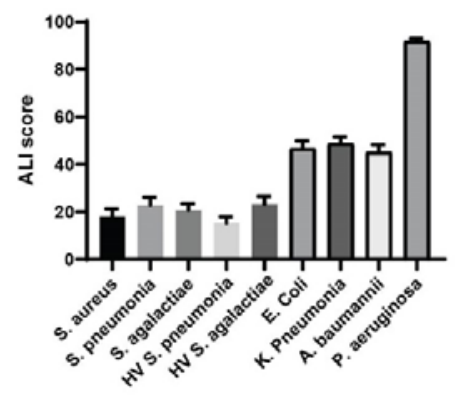

Highly virulent
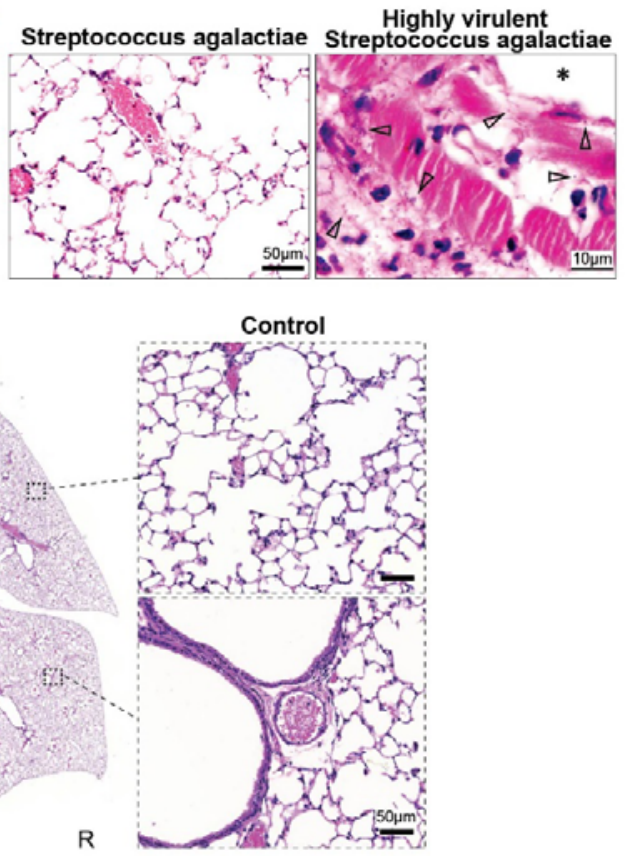

C
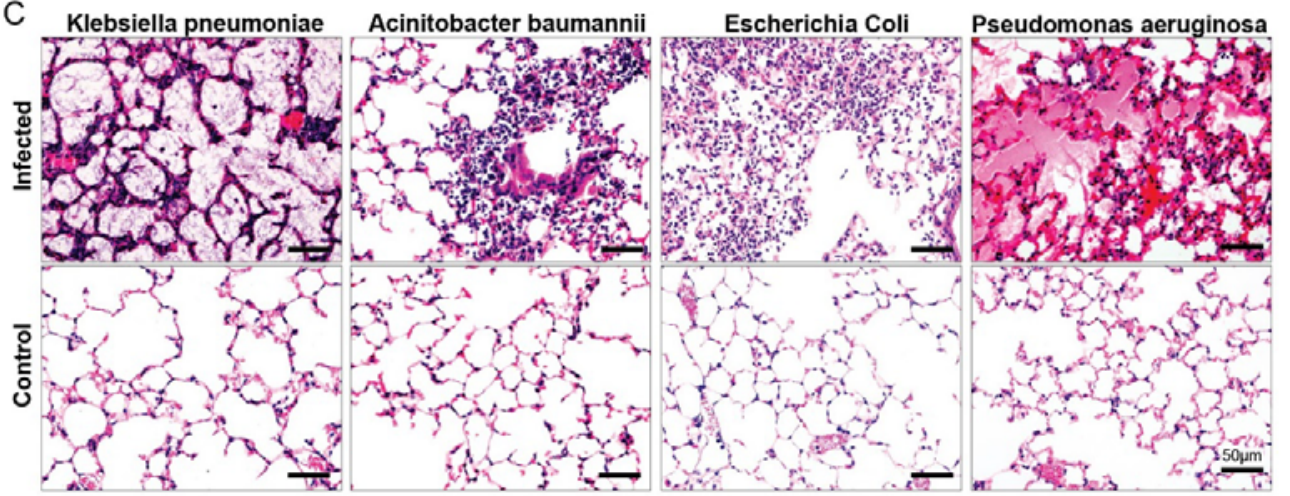
bioRxiv preprint doi: https://doi.org/10.1101/2021.05.15.444319; this version posted May 15, 2021. The copyright holder for this preprint (which was not certified by peer review) is the author/funder, who has granted bioRxiv a license to display the preprint in perpetuity. It is made available under aCC-BY-NC-ND 4.0 International license.

Figure 3
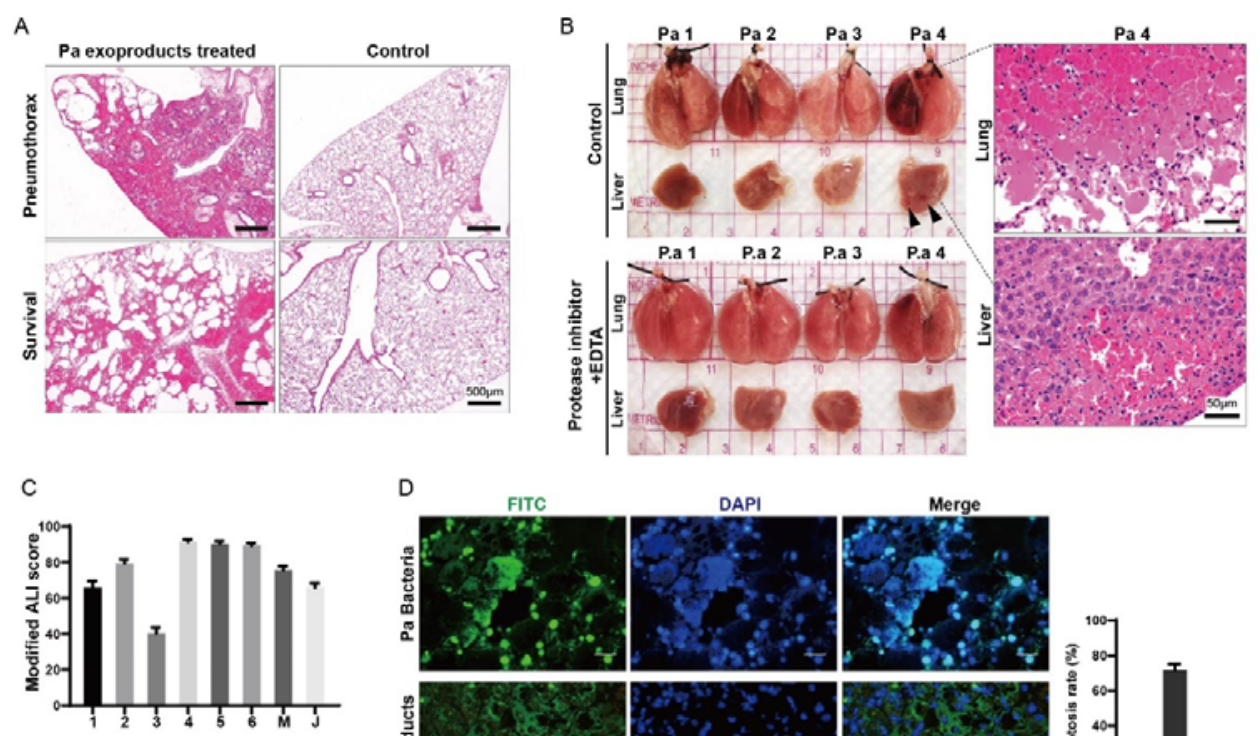

E

D
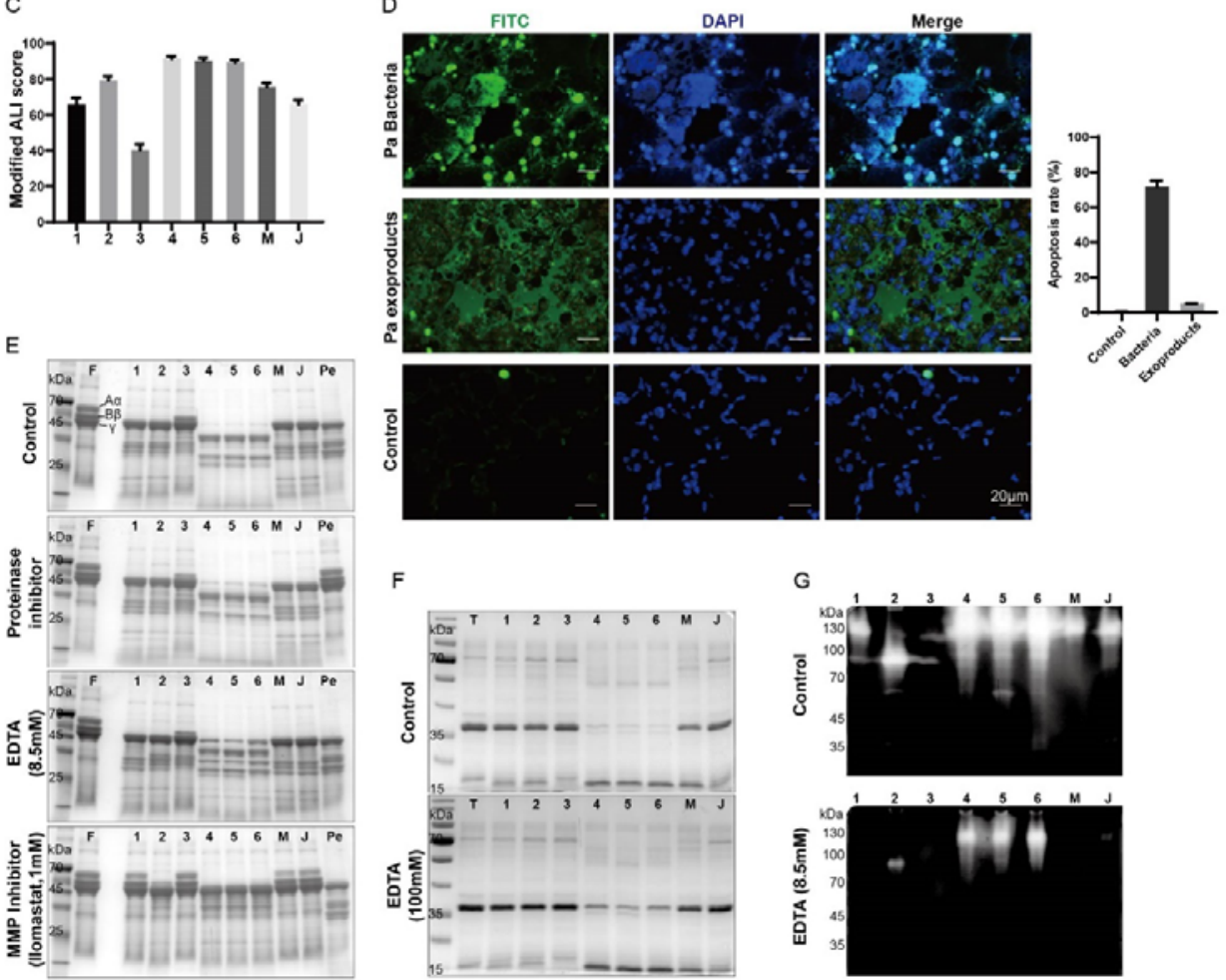

F

G
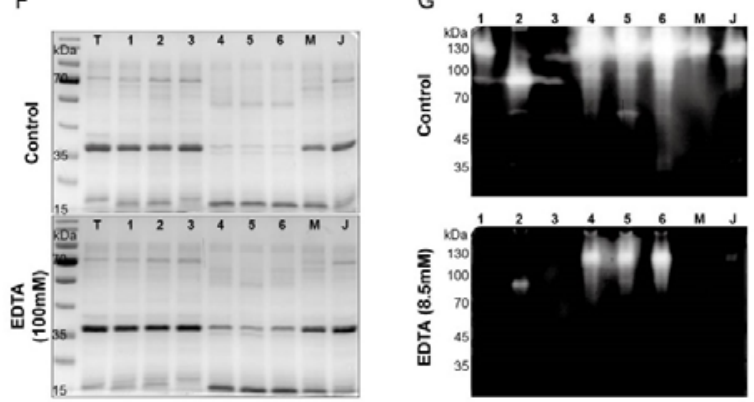
bioRxiv preprint doi: https://doi.org/10.1101/2021.05.15.444319; this version posted May 15, 2021. The copyright holder for this preprint (which was not certified by peer review) is the author/funder, who has granted bioRxiv a license to display the preprint in perpetuity. It is made available under aCC-BY-NC-ND 4.0 International license.

Figure 4
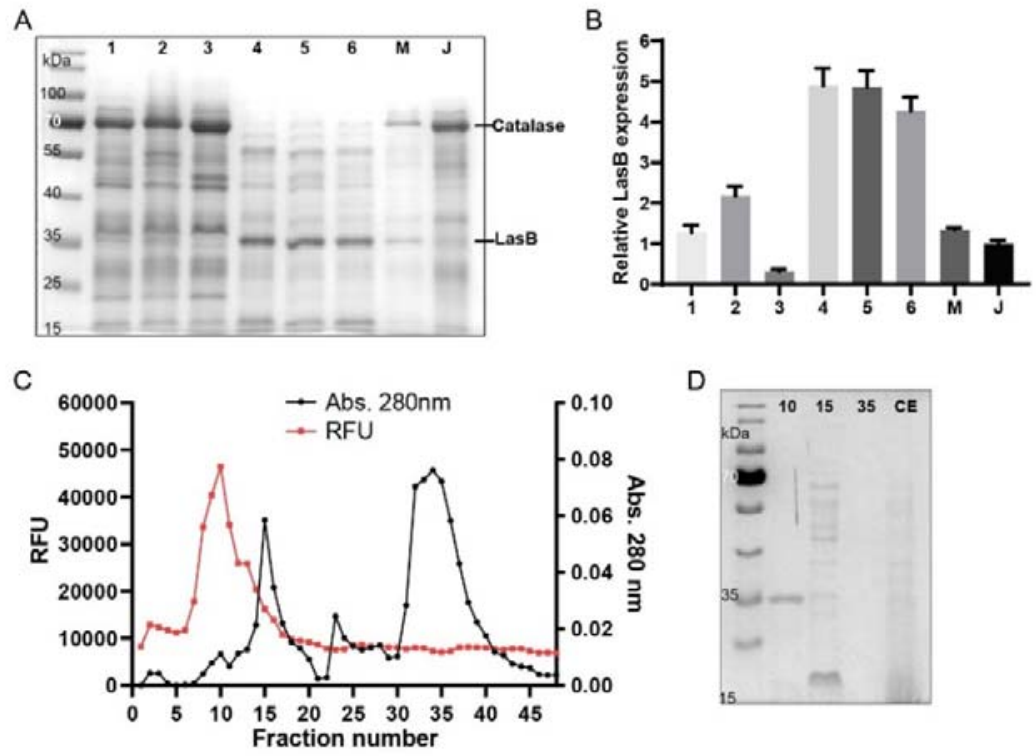

E

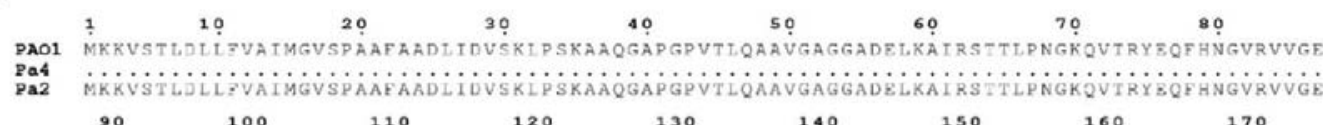

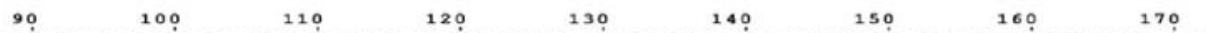

PAO1 RITEVRGFCKSVAAORSGHFVANIAADLPGSTTAAVSAEOVLAOARSLRAOCRZTENDKVELVIRLGENNIAOLVYNVSYLIPCECI

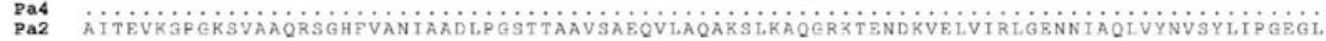

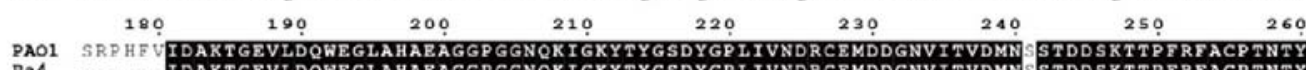

Pa4

Pa2 SRPH IDAKTGEVLDQWEGLAHAEAGGPGGNOKIGKYTYGSDYGPLIVNDRCEMDDGNVITVDMNGSDDSKTTPERFACPTNTYY

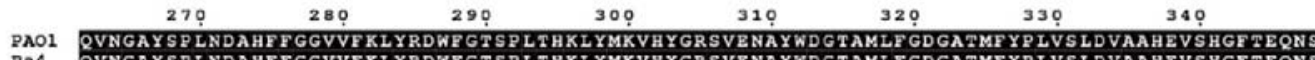

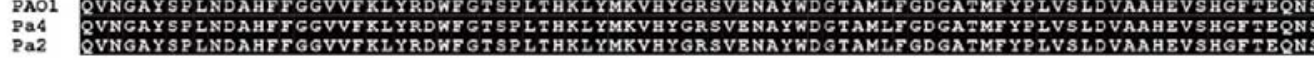

370

380

390

400

$410 \quad 420$

430

PAO1 GLIYRGQSGGMNEAFSDMAGEAAEFYMRGKNDFLIGYD IKKGSGALRYMDQP SRDGRS IDNASQYYNGIDVHHSSGVYNRAFYLLA

440

450

460

470

480

490

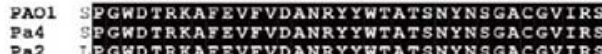

RNYSAADVTRAFSTVGVTCPSAI

TPGDTRKAFEVFVDANRYYWTATSEYNSGACGVTRSAORRNYSAADVTRAF STVGVTCP SA 
bioRxiv preprint doi: https://doi.org/10.1101/2021.05.15.444319; this version posted May 15, 2021. The copyright holder for this preprint (which

was not certified by peer review) is the author/funder, who has granted bioRxiv a license to display the preprint in perpetuity. It is made available under aCC-BY-NC-ND 4.0 International license.

Figure 5

A

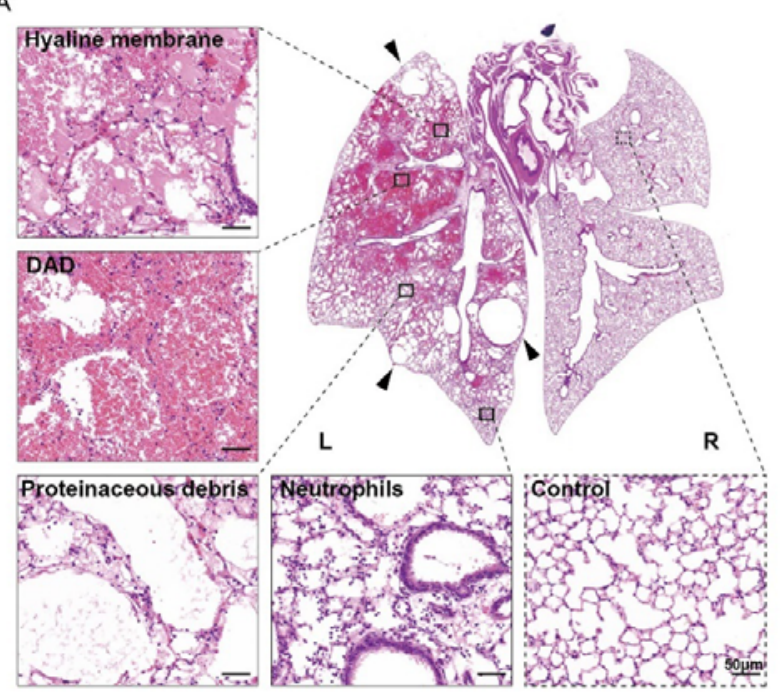

C
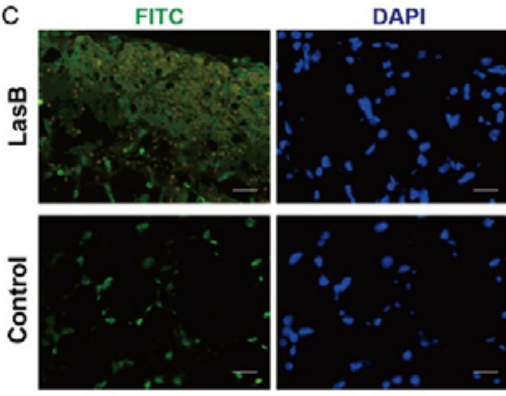

$\mathrm{H}$
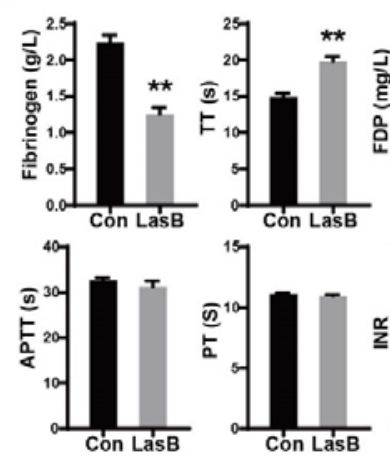

B

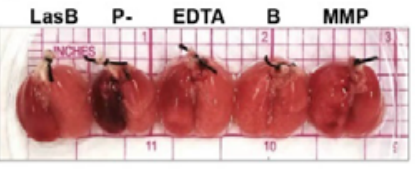

D
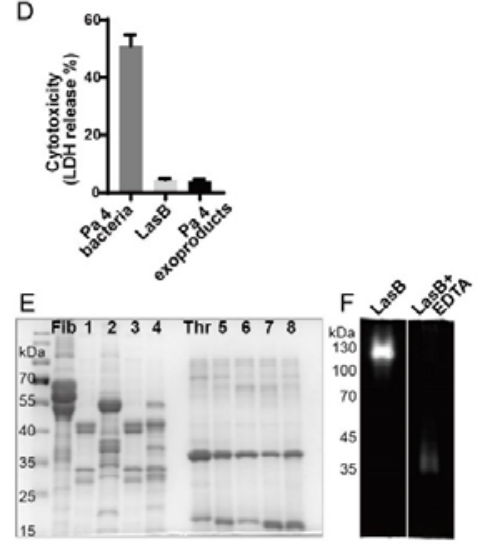

Merge
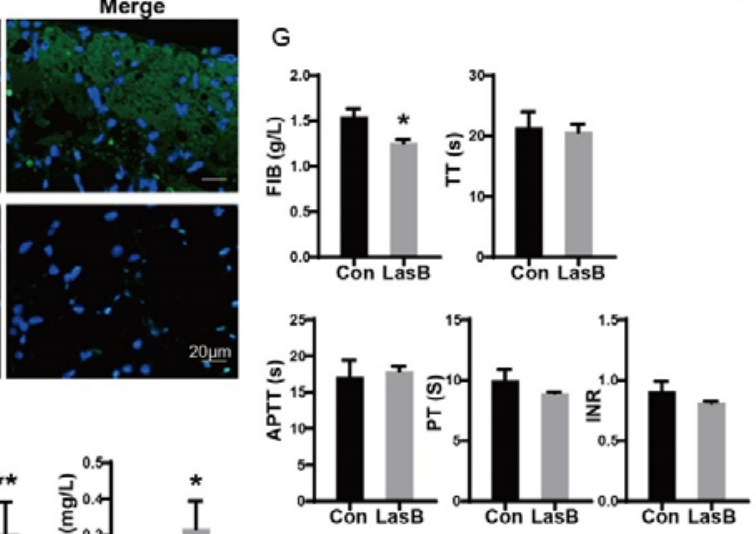
bioRxiv preprint doi: https://doi.org/10.1101/2021.05.15.444319; this version posted May 15, 2021. The copyright holder for this preprint (which

was not certified by peer review) is the author/funder, who has granted bioRxiv a license to display the preprint in perpetuity. It is made available under aCC-BY-NC-ND 4.0 International license.

Figure S 1

A

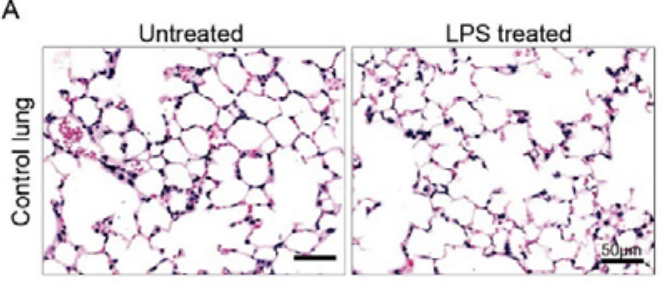

C

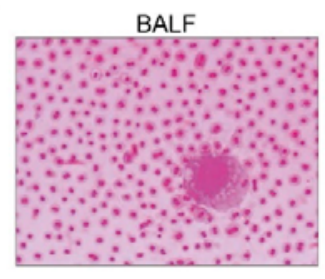

B

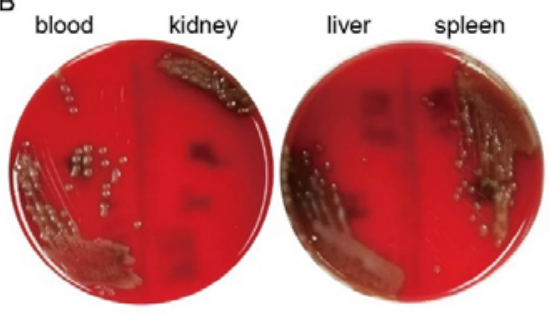


bioRxiv preprint doi: https://doi.org/10.1101/2021.05.15.444319; this version posted May 15, 2021. The copyright holder for this preprint (which

was not certified by peer review) is the author/funder, who has granted bioRxiv a license to display the preprint in perpetuity. It is made available under aCC-BY-NC-ND 4.0 International license.

\section{Figure S 2}

A

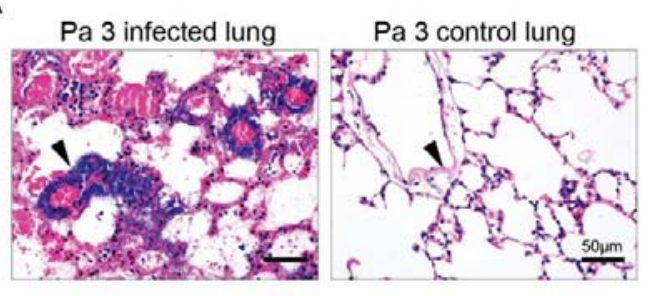

B

$18 \mathrm{~h}$

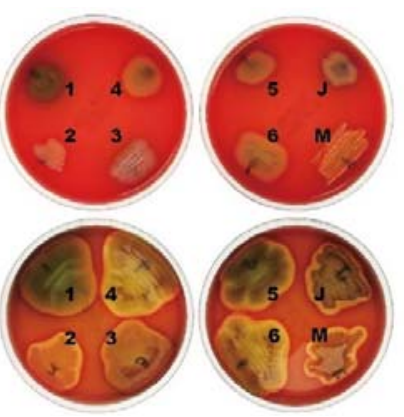


bioRxiv preprint doi: https://doi.org/10.1101/2021.05.15.444319; this version posted May 15, 2021. The copyright holder for this preprint (which was not certified by peer review) is the author/funder, who has granted bioRxiv a license to display the preprint in perpetuity. It is made available under aCC-BY-NC-ND 4.0 International license.

\section{Figure S 3}

A

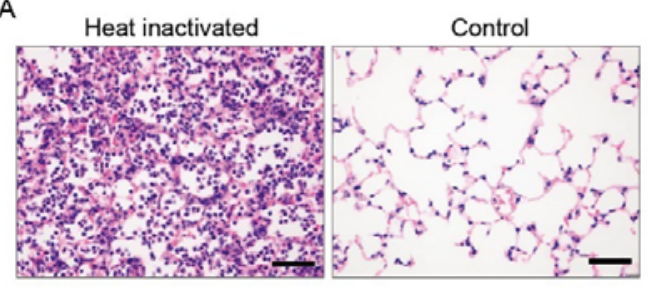

B

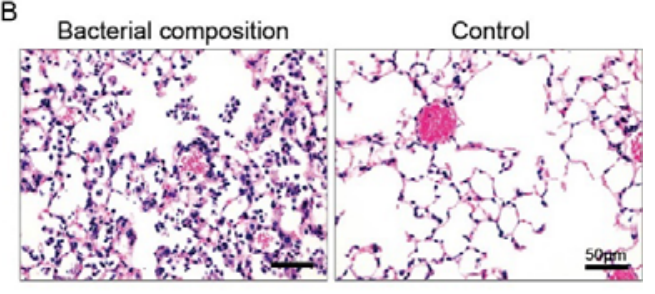

